\title{
Form and Function of Verbal Ablaut in Contemporary Standard German
}

\author{
Bernd Wiese \\ Institut für Deutsche Sprache, Mannheim \\ Dedicated to Peter EISENBERG \\ ON THE OCCASION OF HIS SIXTY-FIFTH BIRTHDAY
}

\section{Contents}

1 Introduction

1.1 Umlaut and $e / i$-alternation

1.2 Ablaut patterns

1.3 Morphological models

1.4 Stems and stem forms

2 Forms of ablaut

2.1 Vowel alternations

2.2 Expression types

2.3 Change of quality type and change of complexity type

2.4 Ablaut vowels

2.5 Change of quantity type

2.6 Simple ablaut and full ablaut

2.7 Special present tense formations

3 Functions of ablaut

3.1 Functional types

3.2 Syncretisms

3.3 Form-function-relation

4 Inflectional classes

4.1 Ablaut classes

4.2 Ablaut class membership

4.3 Ablaut class markedness

4.4 I-base stems and ablaut classes

4.5 Non-I-base stems and ablaut classes

5 Ablaut: an integrated view

6 Conclusion

Abstract. The multiple gradations of German strong verbs are but manifestations of a rather uncomplicated system. There is a small number of ways to make up ablaut forms; 
these types of formation are identifiable in formal terms and, what is more, they have definite functions as morphological markers. Using classifications of stem forms according to quality, complexity and quantity of vowels, three types of operations involved in ablaut formation are identified. Ablaut always includes a change of quality type or a change of complexity type, and in addition it may include a change of quantity type. Ablaut forms are clearly distinguished as against bases (and against each other): their vocalism meets a defined standard of dissimilarity. On this basis, gradations are collected into inflectional classes that are defined in strictly synchronic terms. These classes continue the historical seven classes known from reference grammars. For the majority of strong verbs, membership in these classes (and thus ablaut) is predictable.

\section{Introduction*}

\subsection{Umlaut and e/i-alternation}

Stem changes that function as morphological markers play an important rôle in the grammar of Contemporary Standard German (henceforth, 'German' for short). German verbs may have up to five stems exhibiting different stem vowels. As for 'strong' verbs such as SPRECHEN" ${ }^{\mathrm{w}}$, traditional custom distinguishes three primary tense stems (primäre Tempusstämme, cf. FabriciusHansen 1977: 194). Forms that show these stems are (among others) the infinitive (sprech-en), the form of the 1st person singular indicative of the past (sprach) and the past participle (ge-sproch-en), respectively. ${ }^{1}$ In descriptive grammars, these three verb forms are used as 'principal parts'; as a rule, these forms should suffice to enable users to derive all forms of the verb under discussion. It is implied that the derivation of additional stems conforms to regular patterns. As exemplified by the secondary stems of SPRECHEN ${ }^{\mathrm{W}}$ (viz. the secondary present tense stem sprich, which occurs in the 2nd and 3rd person singular indicative of the present and in the imperative, and the secondary past tense stem spräch, which occurs in the subjunctive of the past), these regular patterns of stem formation are e/i-alternation and umlaut.

Umlaut may be construed as form alternation ("Formabwechslung", Kruszewski 1881: 19) between basic forms in back vowels and derived forms in front vowels (hence the involved vowel change is characterised as "front-

\footnotetext{
Earlier versions of this paper were presented at the Zentrum für Allgemeine Sprachwissenschaft, Typologie und Universalienforschung (ZAS), Berlin, in November 1997, and at the Generative Grammatik des Südens (GGS) 2004 conference, Mannheim, in May 2004. Special thanks to Kate Chapman for stylistic help.

Author's address: Bernd Wiese, Institut für Deutsche Sprache, R5, 6-13, 68161 Mannheim, Germany.E-mail:wiese@ids-mannheim.de

1 Forms of words (and forms of stems) are given in standard orthography using lowercase letters. Names of words and lexemes appear in small capitals and are superscripted with 'w, and 'L, respectively. In tables, superscripts may be dropped for readability.
} 
ing", Zwicky 1967). As every vowel or diphthong that allows umlaut has a unique umlauted counterpart (and vice versa) there is no need to list umlauted secondary stems. Given that the primary present and past tense stems of, say, FAHREN $^{\mathrm{W}}$ are fahr and fuhr, and provided that secondary stem formation is regular, it is derivable that the secondary stems are fähr and führ.

As concerns primary stems in vowels that cannot undergo umlaut (as exemplified by sprech), secondary stems may be formed by means of e/ialternation. $e / i$-alternation is similar to umlaut as it constitutes a change 'towards $i$ ', too. In the case of umlaut it is back vowels (i.e., ' $i$-distant vowels') that alternate with the related front vowels (' $i$-close or $i$-like vowels'); in the case of $e / i$-alternation it is front vowels (viz. $e$ or, in rare cases, $\ddot{o}$ or $\ddot{a}$ ) that alternate with $i$. The 'target' of the change is again unique. ${ }^{2}$ It is true, some verbs lack one or both of the secondary stems. However, if secondary stems are formed at all, their formation for the most part conforms to a uniform and predictable pattern. ${ }^{3}$

\subsection{Ablaut patterns}

While formation of secondary stems conforms to regular patterns, vowel alternations between primary stems do not seem to fit into a comparably systematic picture. Traditionally, these alternations are taken care of in terms of ablaut patterns or gradations ('Ablautreihen'). The verb SPRECHEN ${ }^{\mathrm{W}}$ would be a member of the fourth class of strong verbs, the gradation of which is $e-a-O$ (which provides the principal parts sprechen-sprach-gesprochen). If each and every variant of vowel change between the three primary stems of German verbs is to be taken into account, nearly forty patterns have to be established, many of which are found with one verb only. In addition, there are a number of irregular verbs ('anomalies', Grimm 1870: 908, Paul 1917: 259-276) that show vowel alternations. Excluding these, by strong verb I shall refer to any verb that has stem formation by vowel change but does not have past tense and/or past participle stem formation by means of a dental suffix (as do the weak verbs). ${ }^{4}$ Lists of (stems of) strong verbs are given in Sections 4.4 and 4.5 , infra.

2 The target vowel of $e / i$-alternation is short 'if possible' (cf. Section 2.6, infra).

${ }^{3}$ On the formation of secondary past tense stems see Eisenberg (1997). There are some deviations in subjunctive formation; details and conditioning factors are discussed in Paul (1920: 211-212).

${ }^{4}$ This also excludes the past-present verbs WISSEN $^{\mathrm{w}}$, DÜRFEN ${ }^{\mathrm{w}}$, KÖNNEN $^{\mathrm{W}}$, MÖGEN ${ }^{\mathrm{w}}$, MÜSSEN $^{\mathrm{w}}$, SOLLEN ${ }^{\mathrm{w}}$, and in addition WOLLEN ${ }^{\mathrm{w}}$, which, from a synchronic point of view, belongs to this group), the irregular weak verbs ('Rückumlautverben'), and the so-called 'mixed verbs', which show partly strong forms and partly weak forms. SEIN ${ }^{\mathrm{W}}$ 'to be', 
Table 1 (next page) displays the ablaut patterns that are assumed in the Duden-grammar (Drosdowski et al. 1995: 125, anomalies excepted). The vowels are listed in standard order (infinitive - past indicative - past participle). Numbers in parentheses after the infinitives of the verbs refer to the number of (non-derived) verbs that select the respective ablaut pattern (according to the Duden-grammar). ${ }^{5}$ However, in contrast to the practice in the Duden-grammar, which arranges patterns according to frequency, gradations in Table 1 are collected into seven classes, which will be defined in strictly synchronic terms below. These classes continue the historical seven classes known from reference grammars (e.g., Paul 1989; Curme 1922); the usual numbering is kept in order to facilitate simple and intuitive references. Vowel notation follows Kohler (1995: 169-175, 'phonetic-phonematic transcription').

Such an arrangement highlights certain patterns that go beyond single gradations. Not less than twelve gradations exhibit /o:/ or $/ \mathrm{J} /$ in both the past indicative and the past participle. It is mainly the verbs of the historical second class that follow this pattern, but many have joined this class in Modern German. Moreover, this $o$-o-pattern is only one among others that transcend single gradations; other classes, too, show notable uniformities (which are made to stand out in Table 1 by bold face). Order according to frequency (as in the Duden-grammar) obliterates the class-related conformities beyond recognition. (The twelve gradations that exhibit the $o$-o-pattern are listed as the 4th, 5th, 7th, 13th, 18th, 19th, 20th, 22nd, 28th, 36th, 37th and 38th gradation, respectively!)

Similar treatments are even found in work that is explicitly theoretical in orientation. The resulting complete disfigurement often serves as a basis for denying the existence of a system of ablaut in German. Richard Wiese (1996: 113), who presents ablaut patterns in alphabetical order by the stem vowels of infinitives, arrives at the conclusion that ablaut "is, synchronically, a totally unpredictable vowel change [...]." This opinion is quite common and may well be addressed as the received view. Even standard reference grammars now tend to treat strong verbs as 'irregular verbs', thus returning to a position

WERDEN $^{\mathrm{w}}$ 'to become', HABEN ${ }^{\mathrm{w}}$ 'to have', TUN ${ }^{\mathrm{w}}$ 'to do', GEHEN ${ }^{\mathrm{w}}$ 'to go' and STEHEN ${ }^{\mathrm{w}}$ 'to stand' are among the anomalous verbs. Furthermore, there are doublets of strong and weak verbs (like WEBEN ${ }_{1}^{\mathrm{W}}$ : weben/wob/gewoben vs. WEBEN $_{2}^{\mathrm{W}}$ : weben/webte/gewebt), which may differ in their syntactic, semantic and/or stylistic properties. See Curme (1922: 315-318) and Helbig \& Buscha (1987: 46-49) for details.

${ }^{5}$ Prefixed and compound verbs are not counted, excepting cases that no longer correlate with simple strong verbs. Note, however, that the huge class of prefixed and compound strong verbs is a major factor that contributes to the importance of strong verbs in German; see Griesbach \& Uhlig (1994). 
entertained by linguists of the 17th century like Schottelius (1663:549, 569$603)$.

\begin{tabular}{|c|c|c|c|c|c|c|c|c|}
\hline $\begin{array}{l}\frac{\tilde{y}}{U} \\
\text { Uू }\end{array}$ & pattern & $\begin{array}{c}\text { example } \\
\text { (number of } \\
\text { verbs) }\end{array}$ & $\frac{\tilde{z}}{\tilde{0}}$ & pattern & $\begin{array}{c}\text { example } \\
\text { (number of } \\
\text { verbs) }\end{array}$ & $\frac{\tilde{a}}{\tilde{U}}$ & pattern & $\begin{array}{c}\text { example } \\
\text { (number of } \\
\text { verbs) }\end{array}$ \\
\hline \multirow[t]{3}{*}{ I } & /aI $1 \mathrm{I} /$ & reiten (23) & \multirow[t]{3}{*}{ III } & $/ \mathbf{I} \quad \mathbf{a} \quad \mathbf{u} /$ & binden (19) & \multirow[t]{3}{*}{ VI } & $/ a \quad$ u: a/ & schaffen (4) \\
\hline & /ai i: i:/ & bleiben (16) & & $/$ I $\quad$ a $\quad$ o/ & spinnen (6) & & /a: u: a:/ & fahren (6) \\
\hline & & & & $/ \varepsilon$ a $\quad \mathbf{J} /$ & bergen $(9)$ & & & \\
\hline \multirow[t]{13}{*}{ II } & $/ \mathrm{I} \quad \mathbf{0} \quad \mathbf{0} /$ & schinden (1) & \multirow[t]{4}{*}{ IV } & $/ \varepsilon$ a: $\mathbf{o} /$ & sprechen $(5)$ & \multirow[t]{13}{*}{ VII } & /u: i: u:/ & rufen (1) \\
\hline & 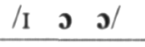 & glimmen (2) & & /e: a: $\mathbf{o /}$ & nehmen (1) & & /o: i: o:/ & stoßen (1) \\
\hline & $/ \varepsilon \begin{array}{lll}\varepsilon & \boldsymbol{\jmath} & \boldsymbol{\jmath}\end{array}$ & fechten (7) & & /e: a: o:/ & stehlen (3) & & $/ a u$ is au/ & laufen (2) \\
\hline & $/ \propto ⿻ 上 丨$ & erlöschen (1) & & /ع: a: o:/ & gebären (1) & & $/ \varepsilon \quad \mathbf{I} \quad \mathrm{a} /$ & hängen (1) \\
\hline & /a & erschallen (1) & \multirow[t]{9}{*}{$\mathrm{v}$} & $/ \varepsilon$ a: $\varepsilon /$ & messen (5) & & $/ \mathrm{a} \quad \mathrm{I} \quad \mathrm{a} /$ & fangen (2) \\
\hline & /au $\mathbf{0} \mathbf{0} /$ & saufen (1) & & /e: a: e:/ & geben (6) & & $/ a$ i $a /$ & fallen (3) \\
\hline & 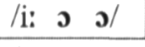 & fließen (11) & & $/ \mathrm{I}$ a: $\varepsilon /$ & sitzen (1) & & /a: i: a:/ & blasen (4) \\
\hline & /i: o: o:/ & biegen (11) & & /I a: e:/ & bitten (1) & & \multirow[t]{6}{*}{ /ai i: aI/ } & \multirow[t]{6}{*}{ heißen (1) } \\
\hline & /y: o: o:/ & lügen (3) & & /i: a: e:/ & liegen (1) & & & \\
\hline & /e: o: o:/ & heben (5) & & \multirow[t]{4}{*}{$/ 0$ a: $\mathrm{d} /$} & \multirow[t]{4}{*}{ kommen (1) } & & & \\
\hline & /E: $\mathbf{0}: \quad 0: /$ & gären (3) & & & & & & \\
\hline & /ø: $0: 0:$ : & schwören (1) & & & & & & \\
\hline & /au o: o:/ & saugen (2) & & & & & & \\
\hline
\end{tabular}

Table 1. Ablaut classes and ablaut patterns (gradations)

In this paper I shall take issue with the view that there is no system of verbal ablaut in Contemporary Standard German. It is true, there is no unique 'operation' (comparable to 'fronting' in the case of umlaut) that ablaut could be reduced to; but certainly this does not imply that ablaut is 'totally unpredictable'. More importantly, it does not follow that ablaut is a matter of mere lexical idiosyncrasy that has to be listed on an item-by-item basis. As will be shown there is a small number of ways to make up ablaut forms; these types of formation are identifiable in formal terms and, what is more, they have definite functions as morphological 'markers'. The seven classes of verbs referred to above are definable on this basis. As a matter of fact, for the majority of strong verbs membership in these classes (and thus ablaut) is indeed 'predictable'. Note, however, that predictability in this sense is not crucial to the assumption that ablaut is not random. Membership in a certain inflectional class is sometimes predictable from other properties of lexemes, sometimes it is not; but then, this is the raison d'être of inflectional classes, not a reason to dispense with them. (You would not specify the endings of Latin noun forms on a word- 
by-word basis only because membership in declensions is not always predictable.)

The thesis of complete synchronic unpredictability of ablaut clashes with the results of traditional grammar; furthermore, it does not take into account the existence of generalisations that were covered by the rule systems in early generative grammar (Ross 1967; Wurzel 1970). To be sure, recent treatments still recognise the existence of (sub-)regularities; an example is: if the past is in $o$, then the past participle is in $o$, too (Wunderlich \& Fabri 1995: 254, note 16; 256). But more often than not such observations are relegated to footnotes or ignored altogether. The reason may be that known regularities apparently do not 'make sense': from a synchronic point of view they appear to be arbitrary.

However, the present paper is intended to show that the apparently so confusingly multiple gradations of German strong verbs are but manifestations of a rather uncomplicated system; as I will show, ablaut in German is characterised by strict regularities and a simple form-function relation. In what follows I shall discuss first (in Section 2) the form of ablaut (What is ablaut?). The rest of the investigation is concerned with the function of ablaut (What is ablaut for?) and moreover the form-function-relation (How does ablaut work?). The rest of the present section serves to address questions of conceptual background and terminology.

\subsection{Morphological models}

The notions used so far have been taken from the traditional word-andparadigm-approach (to use the division of 'models' of grammatical description well-known from Hockett 1954), for which the distinction between words and forms of words is pivotal. Within such an approach it is the formation of forms of verbs that provides the dominant perspective on ablaut (as far as morphology is concerned). Consequently, gradation classes are conceived of as classes of verbs. A verb such as SPRECHEN ${ }^{\mathrm{W}}$ is classified as a member of the fourth class of strong verbs. Forms of verbs (here: spreche, sprichst, ...) are characterised in terms of morpho-syntactic classifications (with respect to person, number, mood, tense and voice), and on this basis they are arranged into paradigms. As an outgrowth, often ablaut alternations are recorded by listing verb forms, namely, the so-called principal parts. Given this starting point, the internal make-up of word forms comes into focus only in the second place. But, of course, verb forms are dissected into stems and endings. Moreover, complex stems are assumed and their formation is investigated. Paul (1917: 189) refers to ablaut, reduplication and suffixation as means of tense stem formation. Nevertheless, stems are usually characterised by recourse to the functions of word forms of which they are parts (e.g., as present tense stem, past tense stem), not in terms of their formal make-up. 
On the other hand, it is precisely the occurrence of certain stems that codetermines to which categories a verb form belongs. Consider past tense stems (past stems, for short). From a morphological point of view, past forms of a verb are what they are for the reason that they are built on past stems. Hence one would want to know what it is that makes a stem a past stem (but taking recourse to its occurrence in certain verb forms would obviously lead into a circle). ${ }^{6}$ What, then, are the formal (expression-related) properties that distinguish past stems?

It was with the advent of structuralism that such questions became a special focus of attention. The analysis of past stems that are, traditionally speaking, formed by adding tense suffixes did not seem to pose problems for an item-and-arrangement-morphology. A past stem such as lobt (of the weak verb LOBEN $^{\mathrm{W}}$ ) could be analysed as combining two morphemes, lob and $t$, the latter having the meaning 'past'; hence the stem lobt is a past stem because it contains a morpheme with the meaning 'past'.

However, the problems encountered by such an approach are notorious (cf. Robins 1959, Matthews 1970, 1972), and it was through the treatment of internal inflection that they became particularly obvious. Past stems of strong verbs such as band (of BINDEN ${ }^{\mathrm{W}}$ ) would not lend themselves to segmentation easily, and various treatments were discussed as to how this could be dealt with (see Harris 1942, Bloch 1947, Nida 1948, and, again, Hockett 1954). The basic problem is that a form such as band simply does not contain a past tense marker comparable to the 'dental suffix' in lob-t. Since band differs from the present tense stem bind only with respect to vocalism, the stem vowel would be the only reasonable candidate. But there are other strong verbs that have stems in $a$ that happen to be no past stems (but present and/or past participle stems as in the case of FANGEN $^{\mathrm{W}}$ or HÄNGEN ${ }^{\mathrm{W}}$ ), and these verbs in their turn have past stems (fing, hing) that show vowels which appear in present or past participle stems of the former ones or still other verbs (cf., e.g., BINDEN ${ }^{\mathrm{W}}$, present stem bind; REITEN ${ }^{\mathrm{W}}$, past and past participle stem ritt). Thus even if you convince yourself that a stem such as ritt may be segmented (say as $r . . . t t$ $+i$ ), it would still be questionable to address the vocalic 'infix' as a tense marker. $^{7}$

The rival approach, item-and-process, as presented by Hockett, would conceive of markers as being constituted by differences between forms (cf.

\footnotetext{
${ }^{6}$ Note that the problem of circularity, which has been made to stand out clearly by Lieb (1983: 173, 178f.), is not restricted to ablaut - characterisations such as the genitive ending - $(e) s$ ' pose similar problems. For further discussion, see Section 5, infra.

7 Matthews (1970: 107) formulates this argument using vocalic suffixes of Italian nouns; the problem is not peculiar to internal inflection.
} 
also Anderson 1992: 61-62). If it is assumed that present tense stems are basic as compared to derived past tense stems, then a process of past stem formation may be identified that derives ritt from reit; the past tense marker is, then, a change from $e i$ to $i$ (more exactly, /aI/ to /I/), and indeed, whenever a strong verb in German has a stem in /aI/ and another stem in / $\mathrm{I}$, the former is a present stem and the latter is a past (and past participle) stem. It would appear, then, that an inspection of relations between stems might open up a viable avenue towards uncovering the system of ablaut.

But in general, inspecting relations between a base form and a derived form does not suffice to establish the interpretation of the derived form. The reason is that different derived forms may compete, as it were, for the same range of application; and in this case, the latitude a derived form has may be cut by other more specific derived forms. An example that will be discussed in more detail below is this: in the case of the verb FECHTEN ${ }^{\mathrm{W}}$, the alternation $/ \varepsilon / \rightarrow / \mathrm{J} /$ serves as a general past marker: both the past stem and the past participle stem show $/ \mathrm{s}$ (the principal parts being fechten-focht-gefochten). The same alternation applies to SPRECHEN ${ }^{\mathrm{W}}$. But in addition, SPRECHEN ${ }^{\mathrm{W}}$ (sprechen-sprach-gesprochen) shows another vowel change, $/ \varepsilon / \rightarrow / \mathrm{a} /$, which marks the stem of finite past forms; in this way the stem in $/ \mathrm{s} /$ is restricted to the non-finite past, viz. the past participle. To cope with this situation itemand-process-models have to integrate some paradigm-like mechanism. ${ }^{8}$

Eventually, the interplay among various forms of a paradigm must not be disregarded if it is to be elucidated how the forms' interpretations come about. Thus an approach is needed that grants paradigms their due status in language systems. At the same time, simply reappointing the traditional word-andparadigm-model would not do. The 'structuralist' insistence on uncovering in detail how forms are made up in order to clarify how form signals function must not be abandoned. An adequate analysis of ablaut must not be limited to dealing with words and word forms but must also regard sub-word items, stems in particular. What is needed, then, is an item-and-paradigm-model or stem-and-paradigm model (cf. Blevins 2003). An approach to morphology (and syntax) that meets these requirements is part and parcel of the larger framework of Integrational Linguistics (Lieb 1983, Eisenberg 1998). Some relevant concepts that are used in the following will now be introduced.

\footnotetext{
${ }^{8}$ Cf. complex rules or disjunctively ordered sets of rules as in Bierwisch (1967) and in Anderson's 'Extended Word and Paradigm Morphology' (Anderson 1982). As Bierwisch (1967: 267, cf. 270) says, "We may conceive of a disjunctively ordered set of inflectional rules as displaying an inflectional paradigm."
} 


\subsection{Stems and stem forms}

An analysis of ablaut must set out to clarify the relations that hold between items that are often referred to as 'tense stems' of strong verbs ('present stems', 'past stems', 'participle stems'); usually, 'primary present stems' are taken to be basic while stems of other types are assumed to be derived. Attempts at grasping the alleged derivational relations in syntagmatic terms (by reference to combinations of morphemes) have turned out to be inadequate. A paradigmatic treatment would appear to be more promising. From this vantage point, a past stem is not construed as a 'combination' of a basic form and an item that signals tense, but as an 'alternative' to the basic form (that occurs in lieu of the latter under certain conditions).

This change of viewpoint brings with it a change in terminology. So far I have followed the older tradition in using terms like 'past stem' and 'participle stem' when referring to morphological 'items' such as sprach, sproch. Another practice that would seem more suitable for a paradigmatic approach treats such items as 'alternants' or 'alternating variants'; from this angle, strong verbs "have more than one form of the stem" (Halle 1953: 46). ${ }^{9}$ As words (such as the verb SPRECHEN ${ }^{\mathrm{W}}$ ) are to be distinguished from their forms (sprechen, spricht, sprach, ...), so, by this approach, stems - that is, stem lexemes - are to be distinguished from stem forms. Consequently, Lieb (1976: 21) introduced the notion of morphological paradigm: as word forms may be put into word-paradigms, stem forms may be put into stem-paradigms (cf. also Lieb 1983: 169, Eisenberg 1998: 29). The relationship between stems and stem forms may be construed analogously to the relationship between words and word forms, as illustrated by the following comparison (see table on next page).

As the example indicates, word-paradigms may be construed as sets of, traditionally speaking, 'grammatical words', a 'grammatical word' being an ordered pair comprising (i) a syntactic unit and (ii) a set of categories to which this unit belongs (this set is called a categorisation); thus spreche is the form of the 1st person singular indicative of the present of the active of SPRECHEN ${ }^{\mathrm{W}}$. Likewise stem-paradigms may be construed as sets of pairs, each of which combines (i) a morphological unit and (ii) a set of categories to which this unit belongs; e.g., sprech (a stem form) is a form of $\operatorname{SPRECH}^{\mathrm{L}}$ (a stem lexeme).

${ }^{9}$ Halle decides to adopt the term stem alternant and uses the term 'stem form' (1953: 47) only informally. 
Here it is still open which categories will serve to categorise stem forms (as indicated by the dots). They will be identified in Section $5 .^{10}$

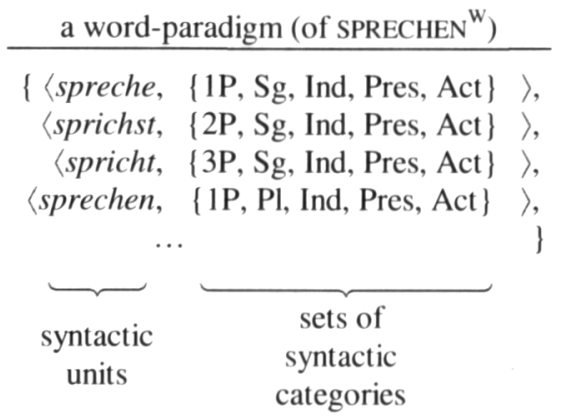

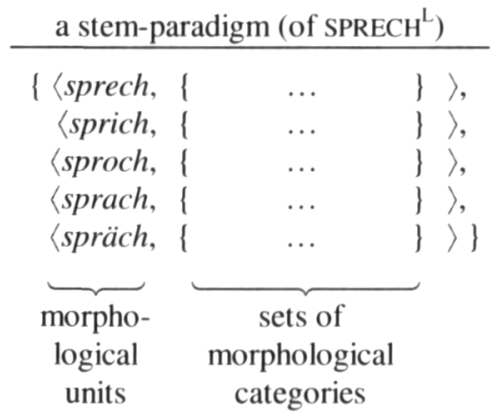

What are (in traditional terminology) strong verbs' tense stems are thus construed as forms of stems. Of course, traditional terms may be used wherever this seems convenient; however, I shall put them in single quotation marks as in: 'past stem'; that is, 'past stem' is short for past tense stem form. Stem forms that occur in principal parts (thus 'primary tense stems') will be referred to as primary forms (of stem lexemes); e.g., sprech, sprach, sproch are the primary forms of $\mathrm{SPRECH}^{\mathrm{L}}$. Likewise I shall use secondary form to refer to stem forms that are, in traditional terms, 'secondary stems'; e.g., sprich and spräch are the secondary forms of $\mathrm{SPRECH}^{\mathrm{L}}$. Primary present forms will be referred to as base forms (or bases, for short); other primary forms may be referred to as ablaut forms. Thus sprech is the base of $\mathrm{SPRECH}^{\mathrm{L}}$ and sproch and sprach are the ablaut forms of SPRECH ${ }^{\mathrm{L}}{ }^{11}$

All morphological items that will be assumed are surface entities, and morphological categories will be based on surface entities: the treatment of ablaut to be proposed will be couched in a surface morphology that does not

\footnotetext{
${ }^{10}$ Cf. also Eisenberg (1998: 213). For Lieb's explication of the concept of paradigm see Lieb (1975, 1980), and in particular Lieb (1992). Cf. also Zwicky's notion of form list (Zwicky 1990: 218). Stems are assigned a major rôle also in Anderson (1992), Aronoff (1994), Stump (2001), and Blevins (2003). Anderson's distinction between stem sets and stems may be compared to Lieb's distinction between stem-paradigms and stem forms.

" (An alternative terminology has major/minor instead of primary/secondary, cf. Halle 1953: 46). Base forms of stems must not be confused with morphological base forms (morphs); morphological units, including forms of stems, are conceived as sequences of morphs (Lieb 1983: 157). For convenience, in the present paper, morphological and syntactic units are referred to by orthographic names in lowercase letters (thus sprech for $\{\langle 1$, sprech $\rangle\}$, versprech for $\{\langle 1$, ver $\rangle,\langle 2$, sprech $\rangle\}$ etc. $)$.
} 
countenance 'underlying' forms (and hence no rules which turn underlying forms into surface forms). ${ }^{12}$

\section{Forms of ablaut}

\subsection{Vowel alternations}

In synchronic treatments, descriptions of ablaut in terms of gradations (ablaut patterns) often differ from those of umlaut in two ways: first, the determination of what umlaut is ('fronting') remains independent of considerations of particular uses that umlaut is put to (e.g., plural marker); on the other hand, setting up ablaut patterns involves reference to the particular functions of stem forms; for instance, a certain gradation may be specified as (Curme 1922: 304):

\section{Pres. ei $\quad$ Past ie $\quad$ Perf. Part. ie}

I shall not adopt this practice; rather I shall investigate the formal and functional sides of ablaut separately. The present section focuses on the formal side. Second, umlaut is conceived of as a two-place relation; on the other hand, it is three - for older language states: four - vowels that are put into relation in ablaut patterns. Once more I shall break with tradition. I shall argue that ablaut in German should be treated as a two-place relation between base forms and derived forms (or their vowels, for that matter).

In the Duden-grammar, a verb such as FECHTEN ${ }^{\mathrm{W}}$ is assigned to the gradation $/ \varepsilon /-/ \supset /-/ \supset /$. As it happens, two out of three vowels of the principal parts are identical. Put differently, the stem $\mathrm{FECHT}^{\mathrm{L}}$ has two, not three primary forms, viz. a base in $/ \varepsilon /(f e c h t)$ and an ablaut form in $/ \mathrm{o} /($ focht). Likewise, the stem MESS $^{\mathrm{L}}$ (which belongs to gradation $/ \varepsilon /-/ \mathrm{a}: /-/ \varepsilon /$ ) has two primary forms, viz. a base in $/ \varepsilon /$ (mess) and an ablaut form in /a:/ $(m a \beta)$, the use of which is - differently from the ablaut form of $\mathrm{FECHT}^{\mathrm{L}}$ — restricted to the past indicative. Thus these two stems show two distinct two-place alternations $(/ \varepsilon / \rightarrow / 0 /$ and $/ \varepsilon / \rightarrow / \mathrm{a}: /$, respectively).

Now consider SPRECHEN ${ }^{\mathrm{W}}$ with the gradation $/ \varepsilon /-/ \mathrm{a}: / / \mathrm{J} /$ (sprech, sprach, sproch). Gradations that comprise three different vowels might be

\footnotetext{
${ }^{12}$ Surprisingly, underlying forms of a pseudo-historical type (as had been introduced in early generative treatments) have been revived in a recent approach to ablaut by Ségéral \& Scheer (1998). They assume, for instance, that the infinitive of the strong verb STOSSEN ${ }^{w}$, viz. / Jto:sən/, has "the synchronic structure /stAUsen/" (Ségéral \& Scheer 1998: 54, italics in the original!), a form that shows a diphthong (as assumed for Common Germanic), long $o$ being a surface product of merging its components. This hardly calls for comment.
} 
taken to require a treatment of ablaut as a three-place relation between forms (or their vowels). However, I shall assume that the stem SPRECH ${ }^{\mathrm{L}}$ exhibits two alternations (two-place each); in fact, $\mathrm{SPRECH}^{\mathrm{L}}$ has $/ \varepsilon / \rightarrow / \mathrm{a}: /$-alternation and $/ \varepsilon / \rightarrow / \partial /$-alternation. The decomposition of three-place ablaut patterns into two-place relations is an important step towards uncovering the system of ablaut in German. As will be shown, the two alternations exhibited by $\mathrm{SPRECH}^{\mathrm{L}}$ are the same (formally as well as functionally) as those alternations that apply separately to MESS ${ }^{\mathrm{L}}$ and $\mathrm{FECHT}^{\mathrm{L}}$; assuming two separate alternations (that may combine) is a precondition for understanding how ablaut works.

\subsection{Expression types}

Not infrequently, forms of strong verbs may be distinguished only by their stem vowels. E.g., the forms versprechen, versprachen, versprochen (of the verb VERSPRECHEN ${ }^{\mathrm{W}}$ ) differ formally only in terms of the stem forms they contain, which in their turn differ only with respect to their stem vowels. Thus, to tell the difference between the verb forms in question it is differences between vowels that one has to rely on, and as far as these are concerned Martinet wrote in a classic contribution to the Manual of Phonetics (Martinet 1957: $263):^{13}$

The first thing, we might even say the only thing, we should expect from the distinctive elements of a language is that they should not get confused with one another. We may therefore suppose that they will tend to become as different from one another as the speech organs involved, will allow; if a language has only three vocalic phonemes, it is likely that the normal, out of context, performance of these three phonemes will be close to $i, u$, and $a$ respectively, i.e. close to the most different vocalic sounds that the organs of speech can produce.

Building on Martinet's suggestion, one expects that such a triad of optimally discernible vowels would be highly welcome when there are three forms to be distinguished in terms of their vowels (as happens with the primary forms of many strong verb stems), and indeed, the most frequent type of a three-vowelablaut pattern in German is precisely $/ \mathrm{I} /-/ \mathrm{a} /-/ \mathrm{U} /$ (exemplified by binden in Table 1). ${ }^{14}$ That this is hardly an accident is confirmed by comparing so-called

\footnotetext{
${ }^{13}$ Based on Martinet (1955); see there, page 62, Section 2.30, and page 151, Section 4.75, on the 'principle of maximal differentiation of phonemes'. Compare also Lindblom's theory of adaptive dispersion (Liljencrants \& Lindblom 1972; for a summary see Lindblom \& Engstrand 1989: 112-114, with references).

${ }^{14}$ Barnes \& Esau (1973: 29) refer to "the need to maximize the contrast between the past and present tenses" as a factor in the diachrony of ablaut. See also Ross (1967: 69) and
} 
onomatopoetic ablaut as it occurs in such double or triple forms as ritschratsch or bimbambum (cf. Dt.Wb., s.v. "I"; Paul 1920: 180-181); some are related to verbs, but not necessarily to strong verbs, cf. Mischmasch, Singsang. Forms that combine reduplication with vowel alternation are often considered so obviously prototypical for ablaut (or 'apophony') that they are used in introducing the term itself (as in Hock \& Joseph 1996: 169). Double forms in German usually have $i$-a-alternation, triple forms are rare but usually conform to the ideal case $;{ }^{15}$ the special position of the $/ \mathrm{I} /-/ \mathrm{a} /-/ \mathrm{v} /$-ablaut pattern fits into the picture.

As regards the remaining three-vowel ablaut patterns of the third and fourth class, the situation is not too different (see Table 1). All of these have bases in front vowels (' $i$-like vowels', viz. $/ \mathrm{I} /, / \varepsilon /, / \mathrm{e}: /, / \varepsilon: /)$, which alternate with forms in open vowels (' $a$-vowels', /a/, /a:/), and forms in rounded back vowels (' $u$-like vowels', viz. $/ \mathrm{u} / \mathrm{/} / \mathrm{/} / \mathrm{o} / \mathrm{/} /$ ). It seems appropriate, then, to distinguish types of stem forms on this basis. I shall refer to stem forms such as bind, sprech, stehl etc. as I-forms, and more generally I shall distinguish I-forms, U-forms, and A-forms. Thus I introduce a classification of stem forms according to vocalism, more specifically, according to vowel quality; diphthongs are integrated into qualitatively determined vowel series adapting the analysis in Kohler (1995: 172). The classification is presented in Table 2 (next page). These types of stem forms are defined in formal (expression-related) terms, not in functional terms, and hence will be called expression types.

In addition, Table 2 introduces two more classifications that will be needed in the following, namely a classification according to complexity (monophthongal vs. diphthongal stem forms, i.e., stem forms containing monophthongs and diphthongs, respectively) and a classification according to vowel quantity: stem forms containing long vowels or diphthongs are long stem forms, stem forms containing short vowels are short stem forms. ${ }^{16}$

Ramat (1987: 324), with reference to Lejosne (1982), on 'changes of polarity' as a characteristic of ablaut, and Kuryłowicz on "[1]e principe de polarisation ou de distances maximum" (Kuryłowicz 1956: 10 et passim). Cf. also Hansen (1964: 21).

${ }^{15}$ With respect to German see Fleischer (1974: 235), for general discussion Mayerthaler (1977: 46-53), and references listed there.

${ }^{16}$ This is a system of classifications for stem forms based on stem vocalism (prefixes are not relevant), not a classification of vowels. True, to propose such a system of classifications implies the assumption that the classifications relate in a reasonable way to properties of vowels. However, no particular theory of (German) vocalism is presupposed. Consider for instance the distinction between long forms (forms that show long vowels such as bieg, fuhr, etc.) and short forms (forms that show short vowels such as ritt, bund etc.). Whether these expression types are eventually defined in terms of vowel length, vowel tenseness or even syllable cut may be left open in the present context. Likewise a decision upon the 
Given a stem vowel, membership of the respective stem form in three classes can be read off Table 2. For instance, sproch (in / $/ \mathrm{J} /$ ) is a short monophthongal U-form. If I wish to refer to subclasses that are defined by the occurrence of a specific vowel, I shall use expressions such as $/ 0 /$-form. If the differentiation in terms of length is to be neglected, I shall use expressions with orthographic vowel names such as o-form (stem form in /o:/ or $/ \mathrm{J} /$ ). The terms I-base, A-base, U-base refer to bases that are I-forms, A-forms, and $\mathrm{U}$-forms, respectively.

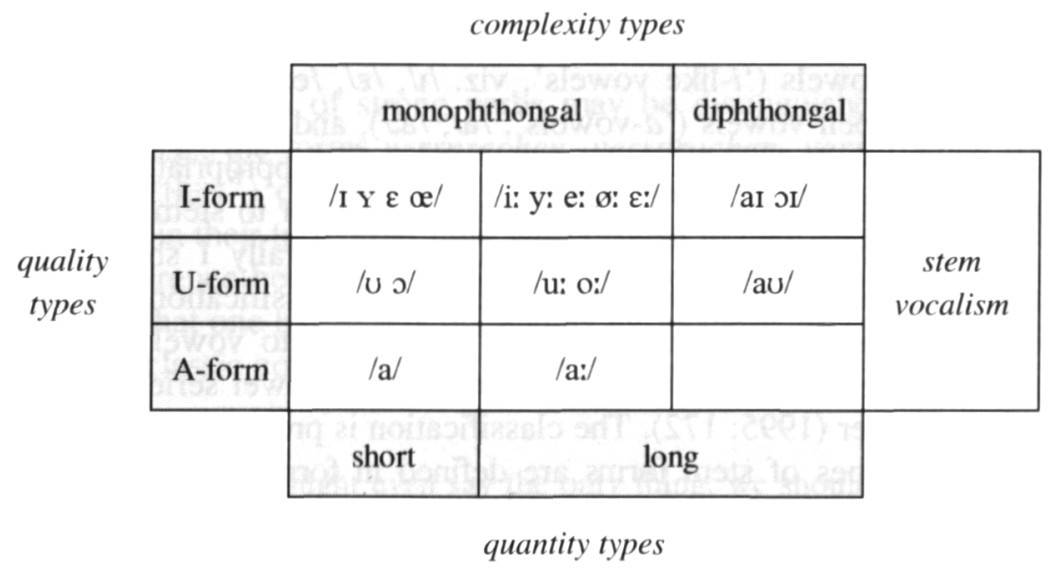

Table 2. Expression types of forms of strong verb stems: stem vocalism

The three classifications that have been introduced serve to define the types of alternations (or 'operations') that are basic constituents of ablaut in German, viz. change of quality type, change of complexity type, and change of quantity type.

\subsection{Change of quality type and change of complexity type}

As noted above, the stems of verbs of the third and fourth class (such as $\mathrm{BIND}^{\mathrm{L}}$ ) each have as their primary forms three forms of distinct quality types (I-form, A-form, U-form). This observation may be generalised. It holds of stems of strong verbs that have a monophthongal base: distinct primary forms of a given stem belong to different quality types; in this case ablaut is change

status of diphthongs need not be made here. The chosen notation meets the necessity to make it clear which stem forms belong to which classes. 
of quality type (or qualitative ablaut, for short). If there is no change of quality type (as with stems of verbs of the first class), there is a change of complexity type: a diphthongal base alternates with a monophthongal ablaut form. On the other hand, mere change of length is not sufficient for ablaut in German: a change of quantity type cannot occur on its own but must be at the same time a change of quality type or complexity type.

Stems of strong verbs have two or three primary forms, and there are three quality types. Thus there are six ways of combining two primary forms (a base and an ablaut form) of different quality types; all of these occur in German as the examples show, cf.:

\begin{tabular}{|c|c|}
\hline base-form, ablaut-form & examples \\
\hline \multirow{2}{*}{ I-form, U-form } & gieß-goss \\
\hline & schind-schund \\
\hline I-form, A-form & mess-maß \\
\hline A-form, I-form & fall-fiel \\
\hline A-form, U-form & schaff-schuf \\
\hline U-form, I-form & ruf-rief \\
\hline U-form, A-form & komm-kam \\
\hline
\end{tabular}

There are two complexity types but there are no diphthongal A-forms. Ablaut forms are never diphthongal in German, thus there are only two ways of combining two primary stem forms of identical quality types, cf.:

$$
\begin{array}{lc}
\text { I-form, I-form } & \text { reit-ritt } \\
\text { U-form, U-form } & \text { sauf-soff }
\end{array}
$$

There is only one way of combining three primary stem forms of different quality types in German, cf.:

I-form, A-form, U-form

$$
\begin{gathered}
\text { sing-sang-sung } \\
\text { sprech-sprach-sproch }
\end{gathered}
$$

No other combinations are allowed in German.

Stems with diphthongal bases usually do not exhibit a change of quality type between their forms. The large majority of these stems (viz. the stems of verbs of the first class) have $e i \rightarrow i$-alternation (thus alternation between I-forms). 
In Contemporary Standard German, ablaut is change of quality type or change of complexity type. ${ }^{17}$ Thus ablaut forms are clearly distinguished as against bases (and against each other): their vocalism meets a defined standard of dissimilarity. The proposed characterisation of ablaut excludes a considerable number of conceivable vowel alternations (e/i-alternation in particular), but, of course, it does not yet define the limits of ablaut. After all, umlaut involves a change of quality type, too (though the direction of umlaut, back $\rightarrow$ front, is inverted as compared to the most prominent cases of ablaut and, moreover, umlaut vowels are not allowed in ablaut forms). In order to approach a more decisive demarcation of ablaut, the particular vowels that occur in ablaut forms have to be considered (the 'ablaut vowels').

\subsection{Ablaut vowels}

The inventory of ablaut vowels is heavily restricted. An approach that characterises alternations in terms of types of forms can account for such restrictions in a natural way. Consider some change of quality type, $\mathrm{A} \rightarrow \mathrm{I}$-alternation for instance (as in fall $\rightarrow$ fiel), thus ablaut forms that are I-forms. This characterisation is rather unspecific and in itself does not fix the ablaut form's vowel. But among $\mathrm{I}$-forms, $i$-forms (i.e., forms in /i:/ or / $\mathrm{I} /$ ) enjoy a special status: $i$-forms are, as it were, 'prototypical' members (or 'best exemplars') of the larger class of I-forms. Hence, if the regularities of ablaut demand an I-form (without imposing any more specific requirements), it may be expected that an $i$-form is called for. Otherwise there should be an additional stipulation to the contrary. Vice versa, a specific regulation has to be assumed to be effective only if the form in question does not belong to the expected prototype. I take it, then, that, in the general case, the particular vowel of an ablaut form need not be specified. To know the quality type and the quantity type will do. Pending any specifications to the contrary, ablaut forms that are I-forms or U-forms are $i$ forms or $u$-forms, respectively; and trivially, A-forms are $a$-forms. (Actually, this 'default rule' might be adopted quite independently of any considerations specific to ablaut.)

There are six ways of changing between quality types, viz. $\mathrm{I} \rightarrow \mathrm{U}-, \mathrm{I} \rightarrow \mathrm{A}-$, $\mathrm{A} \rightarrow \mathrm{I}-, \mathrm{A} \rightarrow \mathrm{U}-, \mathrm{U} \rightarrow \mathrm{I}-$, and $\mathrm{U} \rightarrow \mathrm{A}$-alternation. As may be gathered from the examples given in Section 2.3, only $\mathrm{I} \rightarrow \mathrm{U}$-alternation requires a supplementary regulation; in all of the remaining cases of qualitative ablaut, ablaut forms are invariably $i$-forms, $a$-forms or $u$-forms and thus specification of the ablaut form's quality type is indeed sufficient to fix the ablaut vowel (except for its length).

\footnotetext{
${ }^{17}$ For a discussion of apparent counter-examples see Section 2.7, infra.
} 
Mostly, ablaut forms due to $\mathrm{I} \rightarrow \mathrm{U}$-alternation do not conform to the default rule. As ablaut forms are never diphthongal and as there are two subtypes of monophthongal U-forms, viz. $u$-form and $o$-form, this means that the forms in question are $o$-forms (cf. sprech $\rightarrow$ sproch). However, there is a minority of stems like BIND ${ }^{\mathrm{L}}$, SING $^{\mathrm{L}}$, and TRINK $^{\mathrm{L}}$ that are not subject to this special treatment. The default rule takes over again, and $\mathrm{I} \rightarrow \mathrm{U}$-alternation results in $u$-forms (bund, sung, trunk, which are 'participle stems'). This applies to stems in which the stem vowel is followed by $n d / n g / n k$. As for these "nasal+consonant-stems' (or 'NC-stems', for short), the special regulation that requires $o$-forms is suspended. Its results would not fit into German phonotactics. $^{18}$

As regards stems that show change of complexity type, ablaut forms due to $\mathrm{U} \rightarrow \mathrm{U}$-alternation join the pattern of $\mathrm{I} \rightarrow \mathrm{U}$-alternation. In sum, ablaut forms due to $\mathrm{I} \rightarrow \mathrm{U}$-alternation or $\mathrm{U} \rightarrow \mathrm{U}$-alternation do not conform to the default rule if possible; they are, as a rule, $o$-forms. (Here the proviso 'if possible' accounts for the exclusion of NC-stems.) No other special stipulations concerning ablaut vowels are needed. Given this, it suffices to specify the quality type and the quantity type of an ablaut form in order to fix its stem vowel.

\subsection{Change of quantity type}

Quantitative ablaut (i.e., change of quantity type between stem forms) in German is a poorly understood phenomenon. Reference grammars record patterns of quantitative ablaut on a case-by-case basis (e.g., Curme 1922: 302, 305) but no uniform overall picture emerges (cf. Ségéral 1995: 80-84). Generative rules have also been proposed but the systematic rôle of quantitative ablaut has remained obscure. ${ }^{19}$

As a first step towards uncovering the regularity of quantitative ablaut, two kinds of quantitative change may be distinguished:

\footnotetext{
${ }^{18}$ With these stems, the vowel is followed by a nasal+consonant-cluster or by the velar nasal (which, from a phonotactic point of view, 'counts' as a nasal+consonant-cluster in German) but $/ \delta /$ hardly ever occurs in this context, at least in 'native' stems. Hence the 'aberrant' ablaut formation (that is, the appearance of $/ \mathrm{u} /$ 'instead of' $/ \mathrm{J} /$ ) found with NCstems is regarded as an interference crossing the proper regularities of ablaut (Durrell 1980: 21, Barbour 1982: 343).

${ }^{19}$ See Wurzel (1970); Bittner (1995: 191) offers an amended version of Wurzel's rule (as regards descriptive adequacy) but he does not arrive at a clarification of the relationship between qualitative and quantitative ablaut, let alone of the function of quantitative ablaut.
} 
Short $\rightarrow$ long-alternation. A short base alternates with a long ablaut form.

Examples: /a/ $\rightarrow / \mathrm{i}: /($ fall-fiel), /ع/ $\rightarrow / \mathrm{a}: /($ sprech-sprach), /a/ $\rightarrow / \mathrm{u}: /($ schaff-schuf)

Long $\rightarrow$ short-alternation. A long base (i.e., a diphthongal or a long monophthongal base) alternates with a short ablaut form.

Examples: $/ \mathrm{i}: / \rightarrow / \mathrm{o} /($ gieß-goss $), / \mathrm{au} / \rightarrow / \mathrm{o} /($ sauf - soff $), / \mathrm{aI} \rightarrow \mathrm{I} /($ reit-ritt $)$

(For convenience, I shall also use the terms lengthening and shortening.) The majority of stems do not allow a change of quantity between their forms, that is, long bases correspond to long ablaut forms (e.g., bleib-blieb; stehl-stahlstohl); and short bases correspond to short ablaut forms (e.g., bind-bandbund). The question arises, which types of stems do allow quantitative change at all?

In forms of strong verb stems, short vowels are not allowed to appear before voiced obstruents. ${ }^{20}$ To be sure, this fact does not constitute a peculiarity of verbal stem formation. As is well known, sequences of short vowel plus voiced obstruent are highly marked in German from a phonotactic point of view (Heidolph et al. 1981: 980, 985). ${ }^{21}$ When they do occur at all (e.g., in forms of nouns such as $\mathrm{EBBE}^{\mathrm{W}}$, FLAGGE $^{\mathrm{W}}$ ) this usually points to non-native origin (Paul 1916: 273, 301, from Low German). It does not come as a surprise, then, that strong verb stems such as SCHIEB ${ }^{\mathrm{L}}, \mathrm{HEB}^{\mathrm{L}}, \mathrm{LIEG}^{\mathrm{L}}$, or GRAB ${ }^{\mathrm{L}}$ do not allow quantitative change. In their forms, vowels are long throughout as they are followed by voiced obstruents. ${ }^{22}$ Thus stems are exempt from quantitative ablaut if ablaut vowels are immediately followed by voiced obstruents. The same holds when stem forms end in a vowel (cf. $\left.\mathrm{SEH}^{\mathrm{L}}\right)$.

On the other hand, stem vowels may be either long or short when they are followed by voiceless consonants; cf., e.g., bases in short vowel plus /ç/, /f/, /s/ (sprech, stech, treff, schaff, ess, mess etc.) and in long vowel or diphthong plus /ç/, /f/, /s/ (kriech, riech, trief, schlaf, lauf, ruf, gie $\beta$ etc.). In fact, it is stems that have forms such that the segment immediately following the stem

\footnotetext{
${ }^{20}$ I follow a traditional practice in using the distinction voiced/voiceless, which might be replaced by lenis/fortis (Kohler 1995: 157). Nothing depends on a specific analysis of German consonantism in the present context.

${ }^{21}$ Not only in German, of course; see Kohler (1995: 159 et passim) and, in particular with respect to diachrony, d'Alquen (1979), and the literature quoted there.

${ }^{22}$ This assumes a phonological level where 'final obstruent devoicing has not yet applied'. The final obstruents in question may be voiceless due to final devoicing when stem forms such as schob of SCHIEB ${ }^{\mathrm{L}}$ appear in verb forms such as schob, schobt, schobst. However, final devoicing is not relevant to ablaut regularities (Halle 1953: 46). (No specific account of final devoicing need be presupposed in the present context.)
} 
vowel is a voiceless consonant which make up the proper domain of quantitative ablaut: long $\rightarrow$ short-alternation (e.g., gieß-goss) as well as short $\rightarrow$ longalternation (e.g., schaff-schuf) can be found. ${ }^{23}$ Not all alternations that apply to these stems do involve a change of quantity type (cf. stech-stoch; bratbriet), but, in principle, stems of this type are subject to quantitative ablaut.

Finally, consider sonorant stems, i.e., stems such that vowels are followed by sonorants $(/ \mathrm{r} /, / \mathrm{l} /, / \mathrm{n} /, / \mathrm{m} /, / \mathrm{r} /)$. Stems with long bases ending in liquids (like FRIER ${ }^{\mathrm{L}}, \mathrm{STEHL}^{\mathrm{L}}$ ) behave like those with bases ending in voiced obstruents. Otherwise, change of quality type may be accompanied by change of quantity type. If the sonorant is a nasal, both long $\rightarrow$ short-alternation (cf. $\mathrm{NEHM}^{\mathrm{L}}: / \mathrm{ne}: \mathrm{m} / \rightarrow / \mathrm{nom} /$ ) and short $\rightarrow$ long-alternation $\left(\mathrm{cf}\right.$. KOMM ${ }^{\mathrm{L}}: / \mathrm{kom} / \rightarrow$ $/ \mathrm{ka}: \mathrm{m} /$ ) are possible. If it is a liquid, there may be short $\rightarrow$ long-alternation (FALL ${ }^{\mathrm{L}}: / \mathrm{fal} / \rightarrow / \mathrm{fi}: \mathrm{l} /$ ). But mostly, sonorant stems do not permit a change of quantity type. The most outstanding group of sonorant stems (including, e.g., SING $^{\mathrm{L}}$, TRINK ${ }^{\mathrm{L}}$ ), which forms the core of the traditional third class, is excluded from quantitative ablaut, since long vowels are not allowed before $/ y /$ in German. Actually, all sonorant stems that have short I-bases (not only the ones from the SING $^{\mathrm{L}}$-group) are exempted from quantitative ablaut (e.g., SCHWIMM ${ }^{\mathrm{L}}$, $\mathrm{HELF}^{\mathrm{L}}$ ). This may be regarded as a matter of 'family resemblance' (cf. Section 4.4, infra). In fact, there are only four sonorant stems in German that show primary forms of different quantity types, viz. NEHM ${ }^{\mathrm{L}}, \mathrm{KOMM}^{\mathrm{L}}, \mathrm{FALL}^{\mathrm{L}}, \mathrm{HALT}^{\mathrm{L}}$; these may be listed as lexically marked cases.

Thus two classes of stems of strong verbs can be distinguished: those that do permit quantitative ablaut and those that do not. Membership is, as a rule, determined on the basis of the consonantism of the stem: stems that have ablaut forms in vowel+voiceless obstruent may undergo quantitative ablaut, others must not; exceptions: NEHM ${ }^{\mathrm{L}}$, KOMM ${ }^{\mathrm{L}}$, FALL ${ }^{\mathrm{L}}$, HALT ${ }^{\mathrm{L}}$, subject to, and $\mathrm{BIET}^{\mathrm{L}}$, exempt from quantitative ablaut (cf. note 25 , infra).

Given the set of stems that may undergo quantitative ablaut, it remains to be seen what the triggers are for short $\rightarrow$ long-alternation and for long $\rightarrow$ shortalternation, respectively. Prima facie the situation is somewhat confusing. Consider stems that have bases ending in a voiceless fricative. Even with one and the same post-vocalic consonant, long bases may alternate with long or

\footnotetext{
${ }^{23}$ What is decisive is the consonantism of the ablaut form, which may differ (phonologically, not merely phonetically as in the case of final devoicing) from the consonantism of the base, in particular on account of remaining effects of Verner's law, cf., e.g., SIEDEN ${ }^{\mathrm{w}}$ : siedensott-gesotten; similarly, SCHNEIDEN ${ }^{\mathrm{w}}$, LEIDEN ${ }^{\mathrm{w}}$. (Consonantal alternations, which are exhibited by some strong verbs, will not be discussed as they do not affect the regularities of vowel change.)
} 
short ablaut forms; and short bases may alternate with long or short ablaut forms as well, cf.:

$\begin{array}{ccc}\text { SCHLAF }^{\mathrm{L}} & / \text { lla:f } \rightarrow \text { / lli:f/ } & (\text { long } \rightarrow \text { long) } \\ \text { TRIEF }^{\mathrm{L}} & / \text { tri:f } \rightarrow \text { trof/ } & (\text { long } \rightarrow \text { short }) \\ \text { TREFF }^{\mathrm{L}} & / \text { tref } / \rightarrow \text { tra:f/ } & (\text { short } \rightarrow \text { long) } \\ \text { TREFF }^{\mathrm{L}} & / \text { tref } / \rightarrow \text { trof/ } & (\text { short } \rightarrow \text { short })\end{array}$

As will be shown, it is the interrelation of change of quality, change of complexity and change of quantity that answers for the distribution of short $\rightarrow$ longvs. long $\rightarrow$ short-alternations. First, however, note that the two types of quantitative alternation differ drastically as regards their phonotactic effects. Alternation of vowel quantity is regularly found before voiceless consonants (fricatives, in particular); but, by phonotactic preferences, in this context the appearance of short vowels is 'normal' or expected while the appearance of long vowels is, as it were, 'conspicuous', i.e., marked. Therefore in such contexts long $\rightarrow$ short-alternation results in a phonotactic normalisation of the derived form; for instance, the ablaut form goss /gos/ of GIESs ${ }^{\mathrm{L}}$ shows normal length as opposed to the base gieß /gi:s/. In contrast, short $\rightarrow$ long-alternation regularly results in a phonotactic marking of the derived form; for instance, the ablaut form maß/ma:s/ of MESS ${ }^{\mathrm{L}}$ shows marked length as opposed to the base mess /mes/. ${ }^{24}$ The distinction between length normalisation and length marking provides the key for understanding how quantitative ablaut is put to use for functional purposes (see Section 3).

\subsection{Simple ablaut and full ablaut}

Using classifications of stem forms according to vowel quality, complexity and quantity, I have identified three types of operations involved in ablaut. Ablaut always includes a change of quality type or a change of complexity type, and in addition it may include a change of quantity type. These operations are the constituent parts of two alternation types that make up ablaut in Modern German. I shall look at stems with monophthongal bases first.

All stems of strong verbs that have monophthongal bases show ablaut by change of quality type; there are six ways of changing quality types, but, as a matter of fact, the majority of these stems show $\mathrm{I} \rightarrow \mathrm{U}$-ablaut. As compared to

\footnotetext{
${ }^{24}$ Here is how Jacob Grimm put it: " [...] der auslaut sz liebt vor sich kurzes a [...], selbst in lasz (sine) und lassen (sinere) fügt diesem gebot sich die organische länge ( $m$ hd. lâz lâzen). umgekehrt hält in asz aszen, frasz fraszen, vergasz vergaszen, masz maszen, sasz saszen neben der dehnung auch der inlaut sz stand." (Dt.Wb. s.v. "A".)
} 
other changes of quality type, $\mathrm{I} \rightarrow \mathrm{U}$-alternation shows greater variation, ablaut forms being $o$-forms or $u$-forms; the remaining types show greater regularity, ablaut forms invariably conforming to the default rule given above. Obviously, among changes of quality type, $\mathrm{I} \rightarrow \mathrm{U}$-alternation must be assigned a special status. In fact, given well-known criteria of markedness (Greenberg 1966), these observations indicate that $\mathrm{I} \rightarrow \mathrm{U}$-alternation must be considered the unmarked change of quality type.

With regard to quantitative ablaut, there are two types to be distinguished, viz. shortening, which provides forms of normalised length, on the one hand, and lengthening, which provides forms of marked length, on the other. The junction between change of quality type and change of quantity type turns out to be straightforward. The unmarked change of quality type ( $\mathrm{I} \rightarrow \mathrm{U}$-alternation) is coupled with shortening; otherwise change of quality type is coupled with lengthening. ${ }^{25}$ Remarkably, there is not a single stem that shows $\mathrm{I} \rightarrow \mathrm{U}$-alternation combined with lengthening, nor a single stem that shows another change of quality type combined with shortening. We find it confirmed that $\mathrm{I} \rightarrow \mathrm{U}$-alternation is opposed to all of the remaining changes of quality type. As it is the unmarked type of qualitative ablaut and combines with normalisation of length, it may be referred to as simple ablaut.

Of course, lengthening as well as shortening can apply only if a stem belongs to the class of stems that are subject to quantitative ablaut at all. If a stem from this class shows $\mathrm{I} \rightarrow \mathrm{U}$-alternation, then the ablaut form is invariably short. Unless the base is short anyway, there will be a change of quantity type. E.g., the stems FLIESS ${ }^{\mathrm{L}}$ (long base, /fli:s/) and $\mathrm{SPRECH}^{\mathrm{L}}$ (short base, / $/ \mathrm{preç/)}$ show $\mathrm{I} \rightarrow \mathrm{U}$-alternation; as the vowels are followed by voiceless fricatives, these stems are subject to quantitative ablaut; in this case, either both base and ablaut form are short $\left(/ \int \mathrm{preç/} \rightarrow / \int \mathrm{proç/}\right)$ or a long base alternates with a short ablaut form (/fli:s/ $\rightarrow /$ flos/). In summary, ablaut forms due to simple ablaut are short if possible. ${ }^{26}$

\footnotetext{
${ }^{25}$ This holds also of the four stems in sonorants that are subject to quantitative ablaut, viz. $\mathrm{NEHM}^{\mathrm{L}}$, KOMM ${ }^{\mathrm{L}}, \mathrm{FALL}^{\mathrm{L}}, \mathrm{HALT}^{\mathrm{L}}$. E.g., NEHM ${ }^{\mathrm{L}}$ with a long base and $\mathrm{I} \rightarrow \mathrm{U}$-ablaut shows shortening $($ nehm $\rightarrow$ nomm $)$, FALL $^{\mathrm{L}}$ with a short base and $\mathrm{A} \rightarrow \mathrm{I}$-ablaut shows lengthening $($ fall $\rightarrow$ fiel $)$. As noted above, there is one stem $\left(\right.$ BIET $\left.^{\mathrm{L}}\right)$ that is exceptionally exempted from quantitative ablaut. BIET ${ }^{\perp}$ shows $\mathrm{I} \rightarrow \mathrm{U}$-alternation $($ biet $\rightarrow$ bot $)$ but no shortening, which would be expected on account of the post-vocalic voiceless obstruent (cf. Grimm 1870: 903). Incidentally, the preference for short vowels is generally rather weak in the case of $/ \mathrm{t} /$ as compared to other voiceless consonants (d'Alquen 1979: 196, with references). On SIED $^{\mathrm{L}}$ see note 23 , supra.

${ }^{26} e / i$-alternation is coupled with shortening, too. Hence TRET ${ }^{\mathrm{L}}$ and $\mathrm{NEHM}^{\mathrm{L}}$ show $/ \mathrm{e}: / \rightarrow / \mathrm{I}$ alternation as they are from the class of stems that are subject to quantitative ablaut. Long $\rightarrow$ short-alternation with $\mathrm{GEB}^{\mathrm{L}}$ (Curme 1922: 253) or even $\mathrm{LES}^{\mathrm{L}}$ is now considered non-standard; see the pronouncing dictionaries and cf. also Paul (1917: 229): colloquial
} 
All of the remaining changes of quality type $(I \rightarrow A, A \rightarrow I, A \rightarrow U, U \rightarrow I$, $\mathrm{U} \rightarrow \mathrm{A}$ ) trigger lengthening, i.e., ablaut forms are long if possible. If a stem that is subject to quantitative ablaut shows one of these alternations, then the ablaut form concerned is invariably long. Unless the base is long anyway, there will be a change of quantity type. Hence all of the following ablaut forms are long: sprach (from sprech by $\mathrm{I} \rightarrow \mathrm{A}$-alternation), briet (from brat by $\mathrm{A} \rightarrow \mathrm{I}$ alternation), schuf (from schaff by $\mathrm{A} \rightarrow \mathrm{U}$-alternation), rief (from ruf by $\mathrm{U} \rightarrow \mathrm{I}-$ alternation), and $\mathrm{kam}$ (from $\mathrm{komm}$ by $\mathrm{U} \rightarrow \mathrm{A}$-alternation); the corresponding bases are partly short, partly long.

As a result, stem vowels of ablaut forms due to these alternations are, as a rule, so-called point vowels, that is, vowels of extreme qualities, located, as it were, at the points of the vowel triangle (thus maximally differentiated vowels in Martinet's sense). ${ }^{27}$ These are /i:/, /u:/ and the $a$-vowels, /a:/ and /a/ (which, in Standard German, are differentiated only in terms of length, Kohler 1995: 170). This regularity overrides even strong phonotactic preferences (or aversions, cf. Curme 1922: 14-15), producing stem forms like hielt /hi:lt/, base: halt, and wuchs /wu:ks/, base: wachs, which have long vowels although the stem terminates in a consonantal cluster; cf. also wusch /wu: $\int /$, base: wasch, which has a long vowel before / $/$ / It is crossed only by the ban on long vowels before $/ \mathrm{y} /$, which rules out quantitative ablaut; only in this extremely rare case, $\mathrm{A} \rightarrow \mathrm{I}$-ablaut produces an ablaut form in a non-point vowel (cf. $\mathrm{FANG}^{\mathrm{L}}: / \mathrm{fay} / \rightarrow /$ fin/).

If ablaut vowels are point vowels, this will tend to maximise formal contrasts between base and ablaut forms. Further, as noted above, lengthening usually produces ablaut forms of marked length; thus in these cases the means available for ablaut are, as it were, made use of in full. Hence I refer to this type, covering all changes of quality type except $\mathrm{I} \rightarrow \mathrm{U}$-alternation, as full ablaut.

Vowels of ablaut forms due to $\mathrm{I} \rightarrow \mathrm{U}$-alternation are invariably non-point vowels (viz. /o/, /o:/, / / /); thus the ablaut forms concerned cannot be confused

North German. Secondary stem forms that are formed by means of umlaut do not show quantitative change.

${ }^{27}$ Cf. Martinet (1957: 264): "[vowels that occupy] the corners of the vocalic triangle". As has often been noticed, point vowels have a privileged position in vowel systems (cf., in particular, Jakobson 1941), and it is assumed that the preference for point vowels is related to their favourable articulatory and auditive properties (cf. Stevens 1972). Apparently, ablaut forms that show point vowels are optimal if reliable differentiation and salience are 'desiderata'. 
with forms due to $\mathrm{A} \rightarrow \mathrm{U}$-alternation, which are $/ \mathrm{u}: /$-forms ${ }^{28}$ The special regulation that requires ablaut forms to be $o$-forms in case of $\mathrm{I} \rightarrow \mathrm{U}$-alternation (apart from NC-stems, which, in their turn, allow only short ablaut forms) serves to contribute to the sharp contrast between the two types of ablaut. As summarised in Table 3 (next page), there is a linkage between $\mathrm{I} \rightarrow \mathrm{U}$-alternation, shortening, and non-default ablaut vowels on the one hand side, and between the remaining changes of quality type, lengthening, and default ablaut vowels on the other hand side. The combined effect of opposite regulations concerning ablaut vowels' quality and quantity results in a clearly distinguished vocalism of ablaut forms of stems with monophthongal bases: the sets of ablaut vowels found with simple and full ablaut are disjoint. Thus the two types of ablaut may be conveniently identified by reference to the ablaut vowels involved: simple ablaut is o-ablaut, ablaut forms being $o$-forms in the regular case. It is to be understood that cases where '/ $/ /$ substitutes for $/ \mathrm{d} /$ ' are included. As for full ablaut, three subcases are to be distinguished in terms of ablaut vowels, viz. $i$-ablaut, $a$-ablaut, and $u$-ablaut, ablaut forms being /i:/- or /I/-forms, /a:/- or /a/-forms, and /u:/-forms, respectively.

The distinction simple ablaut vs. full ablaut is drawn in terms of formal properties of stem form alternations; on the other hand, it is functionally relevant: as will be shown in Section 3, these two types of ablaut correspond to two distinct functions of ablaut. Consequently, simple and full ablaut may combine, i.e., there are stems like $\mathrm{SPRECH}^{\mathrm{L}}$ that show both simple and full ablaut (sprech $\rightarrow$ sproch, sprech $\rightarrow$ sprach). On the other hand, $i$-ablaut, $u$ ablaut, and $a$-ablaut, being varieties of full ablaut, cannot combine. Of the five changes of quality type that are covered by full ablaut, $\mathrm{A} \rightarrow \mathrm{U}$-alternation is found with a severely restricted group that comprises only nine stems (cf. Section 4.5, infra), $\mathrm{U} \rightarrow \mathrm{A}$-alternation is found with one stem only $\left(\mathrm{KOMM}^{\mathrm{L}}\right)$. Apart from these, given the quality type of the base, the distribution of varieties of full ablaut is fixed (by the general rule that requires change of quality type): $a$-ablaut is found only with $\mathrm{I}$-bases ( $\rightarrow \mathrm{A}$-alternation), $i$-ablaut is found with other bases $(\mathrm{A} \rightarrow \mathrm{I}$-alternation, $\mathrm{U} \rightarrow \mathrm{I}$-alternation).

\footnotetext{
${ }^{28}$ Ablaut forms formed by $\mathrm{A} \rightarrow \mathrm{U}$-alternation cannot but be long owing to a restriction on the form of the bases concerned; cf. Section 4.5, infra. (On ERSCHALL ${ }^{\mathrm{L}}$ see Section 2.7, infra.)
} 


\begin{tabular}{|c|c|c|}
\hline qualitative ablaut & quantitative ablaut & ablaut vowels \\
\hline $\mathrm{I} \rightarrow \mathrm{U}$ & $\begin{array}{l}\text { shortening } \\
\text { if applicable }\end{array}$ & $\begin{array}{l}\text { /o/, /o:/ } \\
\text { (/u/) }\end{array}$ \\
\hline $\begin{array}{c}\mathrm{A} \rightarrow \mathrm{U} \\
\mathrm{I} \rightarrow \mathrm{A}, \mathrm{U} \rightarrow \mathrm{A} \\
\mathrm{A} \rightarrow \mathrm{I}, \mathrm{U} \rightarrow \mathrm{I}\end{array}$ & $\begin{array}{l}\text { lengthening } \\
\text { if applicable }\end{array}$ & $\begin{array}{c}\text { /i:/, /a:/, /a /, /u:/ } \\
(/ \mathrm{I})\end{array}$ \\
\hline
\end{tabular}

( ) : occurs only in ablaut forms of NC-stems

Table 3. Simple vs. full ablaut (monophthongal bases)

Ablaut as applied to stems that have diphthongal bases differs from ablaut as found with stems that have monophthongal bases only in one respect: usually, there is no change of quality type. Apart from this, the characterisations of simple and full ablaut given above carry over to stems with diphthongal bases.

As for stems with monophthongal bases, simple ablaut has been characterised as combining $\mathrm{I} \rightarrow \mathrm{U}$-alternation with shortening. As regards diphthongal bases, in the absence of a change of quality type, there are two cases of simple ablaut to be distinguished. (i) The base is an I-form, as usual; the ablaut form belongs to the same type. This is $\mathrm{I} \rightarrow \mathrm{I}$-alternation. (ii) The ablaut form is a $\mathrm{U}$-form, as usual; the base form belongs to the same type. This is $\mathrm{U} \rightarrow \mathrm{U}$ alternation. Type (i) is the majority case, type (ii) is the minority case. As is characteristic of simple ablaut, length alternation is shortening, i.e., ablaut forms are short if possible, and again ablaut forms that are U-forms are $o$ forms. Of course, if quantitative ablaut is not applicable, ablaut forms are long, diphthongal bases being long. Cf.:

- REISS $^{\mathrm{L}}$, I-base, subject to quantitative ablaut, the ablaut form is a short $i$ form $($ rei $\beta \rightarrow$ riss $/ \mathrm{rIs} /$ ),

- REIB $^{\mathrm{L}}$, I-base, not subject to quantitative ablaut, the ablaut form is a long $i$-form $(r e i b \rightarrow r i e b / r i: b /)$,

- SAUF $^{\mathrm{L}}$, U-base, subject to quantitative ablaut, the ablaut form is a short $o$ form ( $\operatorname{sauf} \rightarrow$ soff /zof/),

- SAUG $^{\mathrm{L}}$, U-base, not subject to quantitative ablaut, the ablaut form is a long $o$-form ( $\operatorname{saug} \rightarrow \operatorname{sog} / \mathrm{zo}: \mathrm{g} /$ ).

With monophthongal bases, simple ablaut is $o$-ablaut, and, naturally, ablaut found with SAUF ${ }^{\mathrm{L}}$ and $\mathrm{SAUG}^{\mathrm{L}}$ can be subsumed under this type. As regards 
$\mathrm{I} \rightarrow \mathrm{I}$-alternation, a second variety of simple ablaut has to be recognised, which may be referred to as i-monophthongisation. The two subtypes of simple ablaut are in complementary distribution: $i$-monophthongisation is restricted to $e i$-bases; otherwise simple ablaut is $o$-ablaut.

Stems that have diphthongal bases rarely show full ablaut: there are only two or three such stems. They are recognisable by having long ablaut forms while being subject to quantitative ablaut. Change of quality type is possible. HEISS $^{\mathrm{L}}$ (ablaut form: hieß /hi:s/) and LAUF (ablaut form: lief /liff/) are cases in point. (Of course, the ablaut forms cannot be due to simple ablaut, as they had to be short in this case.) As for LAUF ${ }^{\mathrm{L}}$, ablaut is full ablaut also on account of the change of quality type ( $\mathrm{U} \rightarrow \mathrm{I}$-alternation) ${ }^{29}$ In both cases, it is $i$-ablaut.

In sum, diphthongal bases may show ablaut formations familiar from stems that have monophthongal bases, viz. $o$-ablaut and $i$-ablaut. But the majority of stems with diphthongal bases show neither $o$-ablaut nor a variety of full ablaut, but $i$-monophthongisation (that is, $\mathrm{I} \rightarrow \mathrm{I}$-alternation coupled with shortening). ${ }^{30}$

\subsection{Special present tense formations}

As has been pointed out, there are a few cases of $o$ - and $i$-ablaut where bases belong to the quality type that is characteristic of the corresponding ablaut forms, e.g., SAUF ${ }^{\mathrm{L}}$ and HEISS ${ }^{\mathrm{L}}$. However, this is attached to the condition that there be a change of complexity type and the formation of ablaut forms is in conformance with the general patterns. The base forms are peculiar but the alternations still fit into the system of ablaut.

There are a few more cases that show, traditionally speaking, "special present tense formation' ("besondere Art der Präsensbildung", Paul 1917: 200; cf. also Wurzel 1970). Consider the traditional fifth class. As a rule, bases are $e$-forms and there is $a$-ablaut; in addition, there are 'secondary stems' formed by e/i-alternation and umlaut, respectively; cf., e.g., TRET ${ }^{\mathrm{L}}$ : tret $\rightarrow$ trat, tret $\rightarrow$ tritt, trat $\rightarrow$ trät. The 'secondary present tense stems' formed by e/i-alternation occur in verb forms of the $2 \mathrm{nd} / 3 \mathrm{rd}$ person singular present indicative and in the imperative; this conforms to the standard use of

\footnotetext{
${ }^{29}$ Another case is $\mathrm{HAU}^{\mathrm{L}}$ provided its choice-language past form hieb is still considered standard. It has been widely replaced by the weak form haut (Paul 1917: 241).

${ }^{30}$ This is reflected in the usual classification of strong verbs, where verbs that show $i$ monophthongisation make up the first class while verbs like SAUFEN ${ }^{\mathrm{W}}$ and LAUFEN $^{\mathrm{w}}$ are put into the second and seventh class, respectively. SCHEID ${ }^{\mathrm{L}}$, formerly also in the seventh class (compare the adjective BESCHEIDEN ${ }^{\mathrm{w}}$ ), is not subject to quantitative ablaut. Hence, in this case, length of the ablaut form (/Si:d/) fails to signal full ablaut. Consequently, it is now treated as a case of $i$-monophthongisation, and accordingly SCHEIDEN ${ }^{\mathrm{W}}$ is in the first class.
} 
e/i-alternation. But there are three stems, viz. BITT ${ }^{\mathrm{L}}, \mathrm{LIEG}^{\mathrm{L}}, \mathrm{SITZ}^{\mathrm{L}}$, that are special. True, they show the same repertoire of forms as other stems of the same class. Compare, e.g., TRET $^{\mathrm{L}}$ and $\mathrm{BITT}^{\mathrm{L}}$ :

\begin{tabular}{|c|c|c|c|c|}
\hline & /e:/-form & /I/form & /a:/-form & /ع:/-form \\
\hline TRET $^{L}$ : & tret & tritt & trat & trät \\
\hline BITT $^{L}$ : & bet & bitt & bat & bät \\
\hline
\end{tabular}

What is different in the case of $\mathrm{BITT}^{\mathrm{L}}$ (as compared to $\mathrm{TRET}^{\mathrm{L}}$ ) is that the /I/form is used in all present tense forms of the verb. (Each of the three special stems has an I-form in / $/$ / or /i:/ that occurs in the infinitive - bitten, liegen, sitzen - and another I-form in $/ \varepsilon /$ or /e:/ that occurs in the participle gebeten, gelegen, gesessen. Hence the Duden-grammar lists three gradations that are idiosyncratic to these verbs: /I/-/a:/-/e:/, /i:/-/a:/-/e:/, and /I/-/a:/-/e/, cf. Table 1). But evidently, the difference does not pertain to the make-up of stem forms but to their function. From a synchronic viewpoint, BITT ${ }^{\mathrm{L}}, \mathrm{LIEG}^{\mathrm{L}}$, $\mathrm{SITZ}^{\mathrm{L}}$ may be taken to exhibit what may be called extended application of e/i-alternation. At all events, the particularity found with these stems does not pertain to ablaut; there is no ' $i \rightarrow \boldsymbol{e}$-ablaut' (Wurzel 1970: 77). ${ }^{31}$

HÄNGEN $^{W}$ (cf. Paul 1917: 239f.) provides another case where the 'secondary present tense stem' is used in all present tense forms, though in this case it is formed by means of umlaut. As concerns the make-up of forms, $\mathrm{HÄNG}^{\mathrm{L}}$ (hang, häng, hing) is not different from $\mathrm{FANG}^{\mathrm{L}}$ (fang, fäng, fing), which shows ablaut $(/ \mathrm{a} / \rightarrow / \mathrm{I} /$-alternation) as well as umlaut. Again, there is no exception to the above finding that, as far as monophthongal bases are concerned, ablaut requires a change of quality type.

Two more cases have to be mentioned. U-forms may be due to either simple ablaut ( $o$-ablaut) or full ablaut ( $u$-ablaut). Typical examples are:

flie $\beta \rightarrow$ floss $(\mathrm{I} \rightarrow \mathrm{U}$-alternation, shortening, ablaut form: $o$-form) $\operatorname{schaff} \rightarrow \operatorname{schuf}(\mathrm{A} \rightarrow \mathrm{U}$-alternation, lengthening, ablaut form: $u$-form $)$

SCHWÖR $^{\mathrm{L}}$ is a stem that shows $o$-ablaut, the principle parts of the verb SCHWÖREN $^{\mathrm{W}}$ being schwören-schwor-geschworen. But dictionaries and grammars still list the past tense form schwur, usually adding a qualification such as 'obsolete', cf. Drosdowski et al. (1995: 139), or 'elevated', cf. Paul (1917: 235). On account of its vowel, /u:/, schwur must be due to full ablaut.

\footnotetext{
${ }^{31}$ See also Paul $(1917: 219,229)$ and compare Paul's comments on cases where $i$-forms have spread to the whole present tense, e.g., WIEGEN ${ }^{w}$ vs. BEWEGEN ${ }^{w} /$ ERWÄGEN $^{\mathrm{w}}$.
} 
Yet the base, which is an I-form, not an A-form, does not fit into the pattern. Moreover, if schwur ('past stem') and schwor ('participle stem') are assumed to coexist as ablaut forms of SCHWÖR ${ }^{\mathrm{L}}$ in the standard language, then this is a case where two distinct ablaut forms belong to the same quality type, viz. $\mathrm{U}$-form - contrary to the general pattern. ${ }^{32}$

However, this virtually unique situation, if it exists, must be ascribed to a (not yet complete) changeover from one class to another. In Old High German, the verb in question is in the sixth class, but it shows a special present tense formation (Paul 1917: 200). The modern /u:/-form goes back to the sixth class pattern, but the aberrant base vocalism has caused the verb to leave this class. In Contemporary German, it is in the second class, i.e., it shows $o$-ablaut, in conformance with its base vocalism. The old ablaut form has survived for a long time, significantly in the case of a verb that, owing to its meaning ('swear, vow'), may be expected in solemn or ceremonial speech. However, its being abandoned or becoming out of date evinces the efficacy of the synchronic regularities. ${ }^{33}$

While an /u:/-form is an irregular ablaut form if the base is an I-form, $o$-ablaut requires an I-base (unless the base is diphthongal). But again there is one anomalous case. ERSCHALL ${ }^{\mathrm{L}}$ is a stem with an A-base and yet it has the ablaut form erscholl, which, on account of its vowel, $/ \mathrm{J} /$, must be due to $o$-ablaut. The make-up of the ablaut form is inconspicuous, following the model of verbs of the second class (like QUELL ${ }^{\mathrm{L}}$; cf. Middle High German SCHËLL ${ }^{\mathrm{L}}$ ). Again, the base does not fit into the pattern. Actually, the present tense form is taken over from the corresponding weak verb (see Dt.Wb s.v. SCHALLEN $^{\mathrm{W}}$ ); this is a case of suppletion. Moreover, the simple verb SCHALLEN $^{\mathrm{W}}$ usually shows weak forms; the strong past participle is practically missing. As for ERSCHALLEN ${ }^{\mathrm{w}}$, grammars recognise both weak and strong forms as being customary. Diachronically, at least, it is a case of a mixed verb. The present approach discloses and locates its synchronic anomaly (which concerns the present tense form, not the ablaut form). At all events, (ER)SCHALL ${ }^{\mathrm{L}}$

\footnotetext{
${ }^{32}$ A stem that has a U-form as a primary form may still have an umlauted subjunctive form, the non-umlauted counter part of which would be another U-form (STERBEN ${ }^{\mathrm{W}}$ : stürbe vs. gestorben).

${ }^{33}$ See Forssman (1999) on the diachrony of SCHWÖREN ${ }^{\mathrm{w}}$, and also Theobald (1992: 103 $108,136-139$, with references). In the case of SCHWÖREN ${ }^{\mathrm{w}}$, past indicative forms in /u:/ are sometimes listed as the only or as the preferred or more common forms (Curme 1922: 313) Some grammars (e.g., Drosdowski et al. 1995: 135) also list /u:/-forms of the obsolete verb ANHEBEN $^{\text {w }}$ 'begin', but usually not in the case of (AN)HEBEN ${ }^{\mathrm{W}}$ 'lift', and subjunctive forms in /y:/. Basically, the situation is the same as with SCHWÖREN ${ }^{\mathrm{w}}$, but in this case the /u:/forms (and /y:/-forms) are definitely archaic.
} 
is not a 'normal' strong verb stem. On account of its marginal status, it will be disregarded in the following.

Finally, the verb KOMMEN ${ }^{\mathrm{W}}$ is usually assigned to the fourth class of strong verbs (gradation $e-a-o$, cf. NEHMEN ${ }^{\mathrm{W}}$ ) although its 'principal parts' are kommen-kam-gekommen. ${ }^{34}$ Its base vocalism would have to be regarded as deviant. By the present synchronic approach, however, the stem KOMM ${ }^{\mathrm{L}}$ shows ordinary $a$-ablaut ( $\mathrm{komm} \rightarrow \mathrm{kam}$ ): it has one (and only one) ablaut form ( $\mathrm{kam}$ ), which is an A-form, and there is short $\rightarrow$ long-alternation. However, $\mathrm{KOMM}^{\mathrm{L}}$ is the only stem that shows $\mathrm{U} \rightarrow \mathrm{A}$-alternation. ${ }^{35}$

\section{Functions of ablaut}

\subsection{Functional types}

It is customary to distinguish what may be called functional types of stem forms. Usually, these are referred to as 'present stem', 'past stem' and 'participle stem'. In terms of the present approach, the differentiation of functional types constitutes a classification of stem forms (i.e., forms of stem lexemes), namely, a classification that accounts for the stem forms' functions. Of course, these are related to the (functional) categorisations of the forms of verbs that contain the stem forms in question (cf. Lieb 1983: Section 11.3, 1992).

In addition to the named three primary types there are the so-called 'secondary present tense stems' and 'secondary past tense stems'. The differentiation of primary and secondary stem forms is a matter of subclassifying the sets of present and past tense stem forms, respectively. The received terminology (primary-secondary) obviously reflects the assumption that secondary forms are derived from their primary counter-parts. It also points to the observation that this subdifferentiation does not always apply, that is, there are stems such that one or both secondary forms are missing. No doubt, the primarysecondary-differentiation imposes an order of markedness on functional types.

An order in terms of markedness may also be established among primary stem forms. The traditional differentiation of three 'primary stems' tends to give the impression that these three types were on an equal footing, but they

\footnotetext{
${ }^{34}$ In particular in historical grammars but also in reference grammars of Contemporary German; see, e.g., Curme (1922: 311).

${ }^{35}$ It may be noted that some of the forms of anomalous verbs conform to standard ablaut patterns. WES ${ }^{\mathrm{L}}$ functions as a suppletive stem of SEIN ${ }^{\mathrm{W}}$ used in past tense forms; it has $a$ ablaut, wes $\rightarrow$ war (and consonantal change); cf. LES $^{\mathrm{L}}$. Similarly, the past forms of GEHEN ${ }^{\mathrm{W}}$ are built on $\mathrm{GANG}^{\mathrm{L}}$, which shows $i$-ablaut (gang $\rightarrow$ ging); cf. FANG ${ }^{\mathrm{L}}$. WERD ${ }^{\mathrm{L}}$ has an $o$-ablaut form word; cf. WERB ${ }^{\mathrm{L}}$.
} 
are positively not. ${ }^{36}$ Stem forms must not be classified into three types of equal rank; such a classification would be inhomogeneous, a mixing of two criteria that interact in the differentiation of the three functional types, viz. tense and finitude. The traditional three-element classification should be replaced by a system of two classifications: a basic classification according to tense as proposed by Lieb (1978) and a sub-classification in terms of finitude. ${ }^{37}$

I assume, then, a classification into non-past and past forms as a first functional classification on the set of stem forms of strong verbs ${ }^{38}$ This is in accordance with a traditional line of thought that ranks past participles - as the name says - among past forms. The set of past tense forms is subclassified according to finitude: this subclassification sets apart stem forms that occur in finite past verb forms (the 'primary and secondary past tense stems') from those that occur in non-finite (or 'infinite') past verb forms (the latter being tradition's 'participle stems', of course). In its turn, the primary/secondary-distinction imposes a subclassification on the set of finite past tense stem forms in terms of mood. Accordingly, I distinguish between finite past non-subjunctive forms ('primary past stems') and finite past subjunctive forms ('secondary past stems'). To complete the classification system the traditional distinction between 'primary and secondary present tense stems' would have to be accounted for. However, as ablaut concerns the formation of past forms only, this part of the classification system may be left without analysis for purposes of the present investigation. ${ }^{39}$

The proposed system of classifications may be presented by means of a classification tree that is given in Figure 1 (next page). The basic set strong is the set of forms of stems of strong verbs; tense, finitude and mood are the names of the three classifications introduced above. Names of classes are obvious abbreviations. The subclassification of non-past forms is left out. For

\footnotetext{
${ }^{36}$ Compare, for instance, Augst (1975: 251), who assumes that in Modern German a formerly given discrepancy between four 'ablaut grades' and three 'tense grades' (" 4 Ablaut- aber 3 Tempusstufen") has been remedied. This would seem to imply that the three 'primary stems' are differentiated solely in terms of tense (cf. 266: "[...] wird der Vokalwechsel allein mit der Tempusunterscheidung belastet.").

${ }^{37}$ Cf. also Halle \& Marantz (1993), who assume two features, [ \pm past] and [ \pm participle], and see Wunderlich \& Fabri (1995) on the feature [ \pm AGR]. For discussion of the nonmorphemic character of notions such as 'past stem' see Blevins (2003).

${ }^{38}$ Significantly, in the case of 'tense stems' of weak verbs, this distinction is the only one that applies, cf. lob (non-past) vs. lobt (past).

${ }^{39}$ Lieb (1978: 206) distinguishes three types of present tense stem forms because there are two varieties of 'secondary present tense stems'; those that show umlaut are restricted to the 2 nd $/ 3$ rd person singular present indicative while those that show i/e-alternation are used with imperatives in addition.
} 
convenience, I have put the usual names of functional types below the endpoints of the classification system. ${ }^{40}$

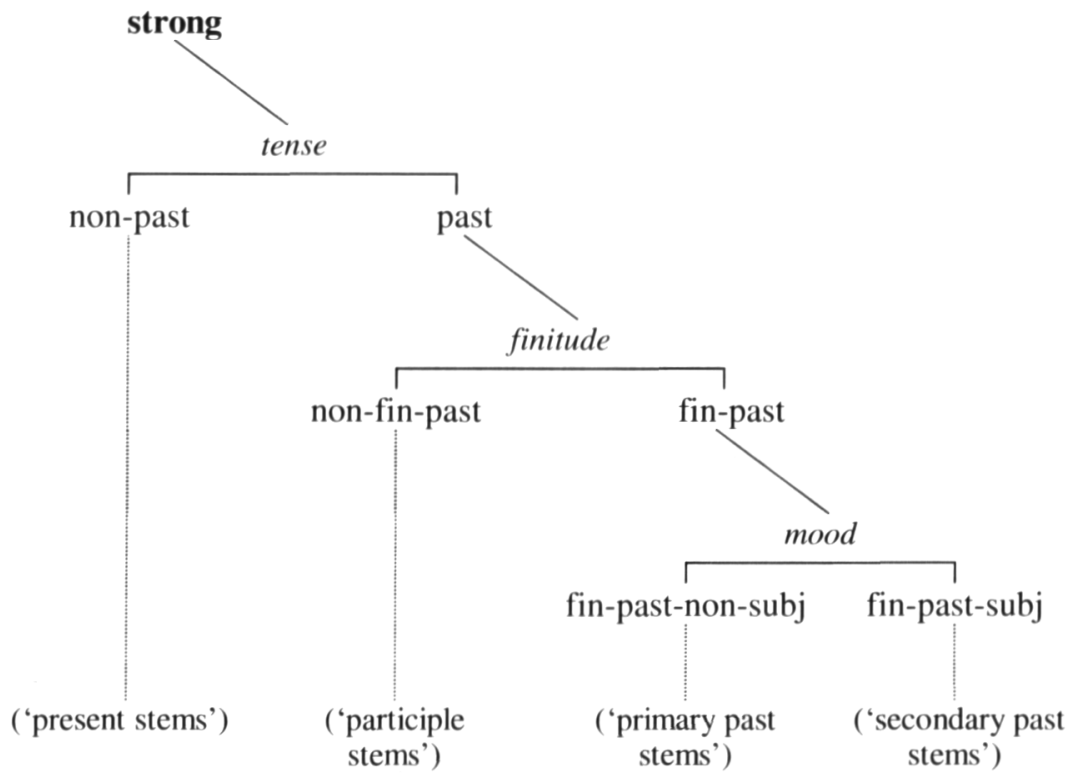

Figure 1. Functional types of forms of stems of strong verbs

As usual, the marked terms of the classifications are put on the right-hand side. The classification system establishes an order of markedness among the classes it provides - from the unmarked (primary) present tense forms to the most highly marked secondary past tense forms.

\subsection{Syncretisms}

Among the three 'primary stems' of a strong verb, two may be identical in expression form. Three types of strong verbs may be distinguished in terms of the identity or non-identity of the vowels of their 'principal parts' (in the order of diminishing number of pertinent verbs): $:^{41}$

\footnotetext{
${ }^{40}$ In a more explicit account categories would have to be relativised to idiolect systems; category names such as 'strong' would have to be replaced by 'strong $(-, S)$ '; see Lieb (1983). The presentation in the present paper is simplified in a number of ways.

${ }^{41}$ This classificatory criterion is found already in grammarians of the 17th and 18th century, in particular in Adelung (see Adelung 1782: 803). More recently, it has been used by Grebe
} 
Type A. 'Participle stem' and 'primary past stem' are identical.

Type B. Three distinct 'primary stems'.

Type C. 'Primary present stem' and 'participle stem' are identical.

Very often this classification is regarded as basic; it is less often analysed or discussed in any detail. However, a closer investigation of the foundation of syncretism patterns turns out to be revealing. The number of patterns of syncretism is multiplied if syncretisms of primary and secondary forms are also taken into account; still, the rationale of syncretisms is simple. Any marked stem form (i.e., any stem form apart from the base) may be 'missing'; if so, the next less specific (i.e., the next less marked) form takes over its office. As regards secondary forms this is obvious from traditional treatments and even from the terminology. Secondary stem forms may be missing, in particular since the vocalism of the relevant primary forms may exclude the possibility of forming them, and it is understood that the primary forms will substitute for them: if a verb stem has no secondary present form the primary present form applies throughout the present tense; likewise, if a verb stem has no secondary past form the primary past form applies throughout the past tense.

It turns out that the same 'logic' applies in case of syncretism between primary stem forms. Consider the stems FECHT ${ }^{\mathrm{L}}$, $\mathrm{SPRECH}^{\mathrm{L}}$ and $\mathrm{MESS}^{\mathrm{L}}$ : Table 4 (next page) lists their primary forms. These are ordered from left to right according to increasing markedness (as established before, cf. Figure 1). Note that the 'participle stems' are put into the middle for this reason (different from the usual listing of principal parts). ${ }^{42}$ The three rows that are preceded by the lexemes' names show the distribution of forms among functional types. At the bottom the expression types are indicated (/ $/$ /-form, / $/$ /-form, or /a:/-form). Table 4 also points out the functional values of the alternations that are involved; this will be explained immediately. What the table says may be detailed as follows.

et al. (1959), Jung (1966), Ross (1967), and Wurzel (1970), among others. Cf. also Ulvestad (1956). And, of course, the syncretisms at issue have not been neglected in historical grammars. Wilmanns (1906) for one uses formal differentiation as his basic classificatory criterion opposing "Verba mit voll entwickeltem Ablaut" (25) and "Verba mit schwächer entwickeltem oder fehlendem Ablaut" (32).

${ }^{42}$ But Adelung (1782: 803) used this order in presenting his classification of strong verbs (and in particular in introducing mnemonic names for the classes of strong verbs), certainly because (non-)identity of the vowels of principal parts is his superordinate criterion. It is also adopted (and again in order to take care of syncretisms) in Johnston (1997). 
functional type:

\begin{tabular}{|c|c|c|}
\hline $\begin{array}{c}\text { 'primary } \\
\text { present stem' }\end{array}$ & $\begin{array}{c}\text { 'participle } \\
\text { stem' }\end{array}$ & $\begin{array}{c}\text { 'primary } \\
\text { past stem' }\end{array}$
\end{tabular}
A. FECHT $^{\mathrm{L}}$
B. SPRECH ${ }^{\mathrm{L}}$
C. MESS ${ }^{\mathrm{L}}$

expression type:

functional value:
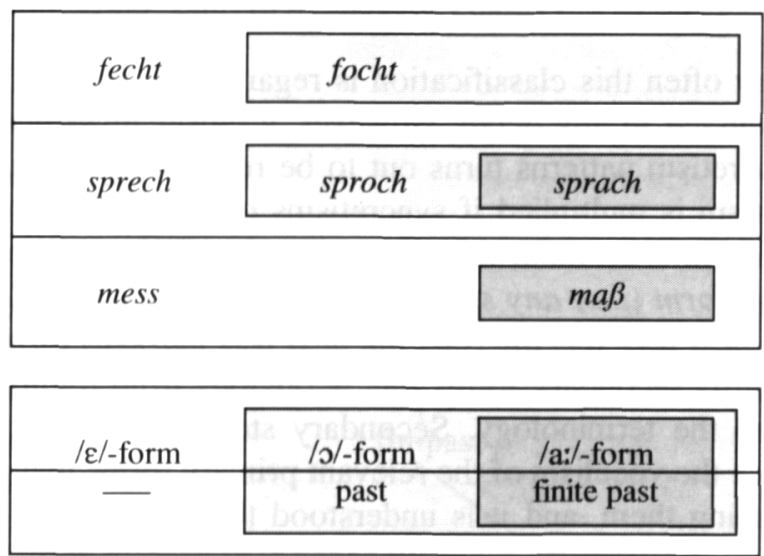

Table 4. Syncretisms among primary stem forms

The three verbal stems FECHT ${ }^{\mathrm{L}}, \mathrm{SPRECH}^{\mathrm{L}}$ and $\mathrm{MESS}^{\mathrm{L}}$ each have a base in $/ \varepsilon /$ (thus an I-base). In addition, $\mathrm{FECHT}^{\mathrm{L}}$ has an $o$-ablaut form (i.e., an ablaut form formed by $o$-ablaut, vide supra, Section 2.6). The $o$-form appears in the past participle and in the finite past (the shaded box indicates the range of application). $o$-ablaut thus functions as a general marker of past tense; put differently, the functional value of $o$-ablaut is past. $\mathrm{MESS}^{\mathrm{L}}$ has (in addition to its base) an $a$-ablaut form (i.e., an ablaut form formed by $a$-ablaut, vide supra, Section 2.6). The $a$-form appears only in the past indicative; again the box indicates the range of application. The functional value of the $a$-ablaut form is finite past, that is, $a$-ablaut serves to mark finite past forms only.

SPRECH $^{\mathrm{L}}$ has (in addition to its base) an $o$-ablaut form and an $a$-ablaut form. The $a$-form appears in the past indicative; again, $a$-ablaut marks finite past. The $o$-form appears in the remaining past tense verb forms, viz. in the past participle; again, $o$-ablaut marks past tense. In this case the $o$-form is restricted to the participle since SPRECH ${ }^{\mathrm{L}}$ has an $a$-form that functions as a finite past form. The existence of this more specific form excludes the appearance of the $o$-form of SPRECH ${ }^{\mathrm{L}}$ in finite past forms of the verb SPRECHEN ${ }^{\mathrm{W}}{ }^{43}$

The bases are found in the domains that are not covered by ablaut forms. Secondary forms further limit the range of application of primary forms; e.g.,

\footnotetext{
${ }^{43}$ See Kiparsky (1973) on the 'Elsewhere-principle' or 'Pāninian principle'; for discussion of its rôle in morphology see, among others, Anderson (1992) and Halle \& Marantz (1993).
} 
the past form sprach is limited to the indicative of the past on account of the existence of the more highly specialised past subjunctive form spräch. The patterning of syncretisms between primary forms turns out to be due to the functional values of ablaut. $o$-ablaut forms are general past forms while $a$-ablaut forms are finite past forms. If a stem does not have a separate finite past form (as is the case with $\mathrm{FECHT}^{\mathrm{L}}$ ), then the general past form takes over; if a stem does not have a general past form (as with $\operatorname{MESS}^{\mathrm{L}}$ ), then the base substitutes for it.

\subsection{Form-function-relation}

Inspection of the three example stems FECHT ${ }^{\mathrm{L}}$, SPRECH ${ }^{\mathrm{L}}$ and $\mathrm{MESS}^{\mathrm{L}}$ has revealed that $a$-ablaut (a variety of full ablaut) serves as a marker of finite past tense, whereas $o$-ablaut (a variety of simple ablaut) serves as a general (unspecific) marker of past tense. These observations may be generalised. It holds not only of these three stems, but also in general: simple ablaut serves as a general past marker; full ablaut serves as a specific finite past marker.

I provide another synopsis of ablaut patterns (Table 5, next page), which is designed to demonstrate these findings. Roman numbers in the first column refer to ablaut classes, i.e., classes of stem lexemes (CLASS I etc.; they will be defined in Section 4.1). The adjacent column lists example stems (as before, stem forms that occur in infinitives are used as citation forms). The next three columns from left to right list the vowels found in '(primary) present stems', 'participle stems' and '(primary) past stems', respectively. If no vowel is given, the one found in the left neighbouring column substitutes for it. For instance, in the case of stems of CLASS I (listed at the top), it is the vowels given for the 'participle stem' that appear in the 'past stem' (thus in the past indicative); with stems of CLASS VI (listed at the bottom), it is the vowels noted under 'present stem' that appear in past participles. The presentation should be self-explanatory. Indeed, it is basically the same as in Table 4 . Shaded boxes indicate ranges of application of ablaut forms.

Instances of $i$-monophthongisation are given at the top. The first example stem $\left(\right.$ REIT $\left.^{\mathrm{L}}\right)$ is one that undergoes a change of quantity type, namely long $\rightarrow$ short-alternation. The minus sign put into the 'participle stem'-column is to draw attention to this fact. There are three more gradations that involve long $\rightarrow$ short-alternation between base and ablaut form, and they are marked in the same way. Similarly, plus signs indicate short $\rightarrow$ long-alternation between base and ablaut form. 
functional type:

\begin{tabular}{|c|c|c|}
\hline 'present stem' & 'participle stem' & 'past stem' \\
\hline
\end{tabular}

\begin{tabular}{|c|c|}
\hline I & $\begin{array}{l}\text { REIT } \\
\text { BLEIB }\end{array}$ \\
\hline II & $\begin{array}{l}\text { SCHIND } \\
\text { GLIMM } \\
\text { FECHT } \\
\text { ERLÖSCH } \\
\text { SAUF } \\
\text { FLIESS } \\
\text { BIEG } \\
\text { LÜG } \\
\text { HEB } \\
\text { GÄR } \\
\text { SCHWÖR } \\
\text { SAUG } \\
\end{array}$ \\
\hline $\begin{array}{l}\text { III } \\
- \\
\text { IV }\end{array}$ & $\begin{array}{l}\text { BIND } \\
\text { SPINN } \\
\text { BERG } \\
\text { SPRECH } \\
\text { NEHM } \\
\text { STEHL } \\
\text { GEBÄR } \\
\end{array}$ \\
\hline V & $\begin{array}{l}\text { MESS } \\
\text { GEB } \\
\text { SITZ } \\
\text { BITT } \\
\text { LIEG } \\
\text { KOMM }\end{array}$ \\
\hline VII & $\begin{array}{l}\text { RUF } \\
\text { STOSS } \\
\text { LAUF } \\
\text { HÄNG } \\
\text { FANG } \\
\text { FALL } \\
\text { BLAS } \\
\text { HEISS } \\
\end{array}$ \\
\hline VI & $\begin{array}{l}\text { SCHAFF } \\
\text { FAHR } \\
\end{array}$ \\
\hline
\end{tabular}

\begin{tabular}{|c|c|c|c|}
\hline $\begin{array}{l}\text { /ai/ } \\
\text { /ai/ }\end{array}$ & $\begin{array}{l}\text { I-form, } \\
\text { diphthongal }\end{array}$ & \multicolumn{2}{|c|}{ I-form } \\
\hline$/ \mathrm{I} /$ & & \multicolumn{2}{|c|}{$/ \mathrm{u} / \mathrm{tan}$} \\
\hline$/ \mathrm{I} /$ & & \multicolumn{2}{|c|}{$|a|$} \\
\hline$|\varepsilon|$ & & \multicolumn{2}{|c|}{$/ 2 /$} \\
\hline$/ œ /$ & & \multicolumn{2}{|c|}{$\begin{array}{ll}12 \\
12 /\end{array} /$} \\
\hline$(/ \mathrm{au} /)$ & & \multirow{2}{*}{\multicolumn{2}{|c|}{$/ 0 /-$}} \\
\hline /i:/ & & & \\
\hline li:/ & & \multicolumn{2}{|l|}{ /o:/ } \\
\hline /e:/ & & \multicolumn{2}{|c|}{ /o:/ U-form } \\
\hline /ع:/ & & \multirow{2}{*}{\multicolumn{2}{|c|}{$\begin{array}{ll}\text { lo:/ } & \text { o-form } \\
\text { lo:/ } & \\
\text { lo:/ } & \end{array}$}} \\
\hline $\begin{array}{l}\text { /ø:/ } \\
\text { (/au/) }\end{array}$ & & & \\
\hline$/ \mathrm{I} /$ & & $/ \mathrm{u} /$ & \multirow{8}{*}{$\begin{array}{l}\text { /a/ } \\
\text { /a/ } \\
\text { /a/ } \\
\text { /a:/ }+ \\
\text { /a:/ } \\
\text { /a:/ } \\
\text { /a:/ A-form } \\
\text { /a:/ }+ \\
\text { /a:/ }\end{array}$} \\
\hline$/ \mathrm{I} /$ & I-form & $10 /$ & \\
\hline $\mid \varepsilon /$ & & $13 x$ & \\
\hline $\mid \varepsilon /$ & & $/ 0 /$ & \\
\hline /e:/ & & $\mid \mathrm{o} /-$ & \\
\hline /e:/ & & /o:/ & \\
\hline /ع:/ & & lo:/ & \\
\hline $\begin{array}{l}/ \varepsilon / \\
/ \mathrm{e} /\end{array}$ & & \multirow[b]{2}{*}{$\begin{array}{l}\mid \varepsilon / \\
/ \mathrm{e} / / \\
/ \mathrm{e} / /\end{array}$} & \\
\hline & $\begin{array}{c}e / i- \\
\text { alternation }\end{array}$ & & $\begin{array}{l}\text { la:/ }+ \\
/ a: / \\
\text { la:/ }\end{array}$ \\
\hline$/ 0 /$ & & \multirow[b]{2}{*}{ orm $<$} & $/ a: /+$ \\
\hline $\begin{array}{l}\text { /u:/ } \\
\text { lo:/ } \\
\text { /au/ }\end{array}$ & & & $\begin{array}{l}\text { /i:/ } \\
/ \mathrm{i} / / \\
/ \mathrm{i} / /\end{array}$ \\
\hline$|\varepsilon|$ & umlaut & \multirow[t]{5}{*}{$/ \mathrm{a} /$} & \multirow{2}{*}{$\begin{array}{ll}/ \mathrm{I} / & \mathrm{I} \text {-form } \\
/ \mathrm{I} / & \text {-for }\end{array}$} \\
\hline$/ a /$ & & & \\
\hline /a/ & & & $/ \mathrm{i}: /+$ \\
\hline $\begin{array}{l}\text { /a:/ } \\
\text { (/ai/) }\end{array}$ & & & \\
\hline $\begin{array}{l}/ \mathrm{a} / \\
/ \mathrm{a}: /\end{array}$ & & & $\begin{array}{l}/ \mathrm{u}: /+ \text {-form } \\
\text { /u:/ }\end{array}$ \\
\hline
\end{tabular}

functional value:

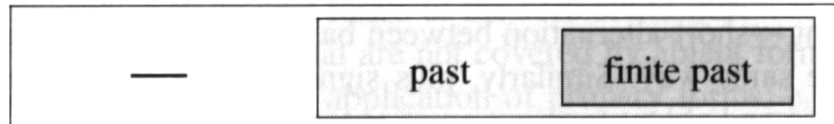

Table 5. Synopsis of ablaut patterns in Contemporary Standard German 
Below that, stems are listed that exhibit only $o$-ablaut followed by stems that show $o$-ablaut and $a$-ablaut. Underneath come gradations that involve only $a$-ablaut, $i$-ablaut or $u$-ablaut. The general arrangement accords with the traditional order of ablaut classes of strong verbs, but VII has been placed between V and VI. Names of the pertinent expression types of ablaut forms have been put into the boxes, thus I-form, $U$-form, A-form; the same procedure applies to the domain of base forms (unshaded area). The arrows are drawn in in order to illustrate clearly the six types of change of quality type there are.

If a base does not belong to the class indicated, the vowel sign is put between parentheses. This concerns only a few diphthongal bases. As stems with diphthongal bases ordinarily do not undergo a change of quality type, these bases belong to the same quality types as do their ablaut forms.

Three stems of CLASS $\mathrm{v}$ and one of CLASS VII have an alternation form in the whole of the present tense that is not due to ablaut. This is indicated by the dotted boxes. In these cases it is the forms occurring in the 'participle stems' that figure as bases for ablaut. (Cf. supra, Section 2.7, on 'special present tense formations'.) In other cases, vowels of 'secondary stems' are not listed.

An uncomplicated picture emerges:

- Simple ablaut serves to mark general past forms. Bases are I-forms; stems undergo monophthongisation if diphthongal (ablaut forms are $i$-forms) or $o$-ablaut if monophthongal (ablaut forms are $o$-forms or, in the case of NC-stems, $u$-forms). Ablaut forms are short if possible.

- Full ablaut serves to mark finite past forms. There is a change of quality type; ablaut forms are $a$-forms, $i$-forms or $u$-forms, and they are long if possible.

In addition, there are two or three stems that have diphthongal U-bases and show $o$-ablaut, and one stem with a diphthongal I-base that shows $i$-ablaut.

In the light of these results, it should be obvious that any approach that derives 'past participle stems' from 'primary past stems' must do violence to the structure of the German ablaut system. The usual order of listing forms of strong verbs must not be misconstrued as a derivational scheme. An attempt to treat ablaut in German as a two-step derivational process (present $\Rightarrow$ past $\Rightarrow$ past participle) as proposed in Ségéral \& Scheer (1998) is bound to fail. By their approach, Ségéral and Scheer are lead to assume that verbs like BIEGEN ${ }^{\mathrm{W}}$ (biegen-bog-gebogen) have distinct underlying stem forms for past participles and finite past forms. But, as a matter of fact, stems of the first and second class conform to the normal pattern that is also found with the weak verbs: they employ one and the same stem form for all (non-subjunctive) past forms, 
including past participles. Even in the case of verbs like $\operatorname{STOSSEN}^{\mathrm{W}}$ (stoßenstieß-gestoßen), Ségéral and Scheer maintain that vowels in past participles are derived from finite past vowels by ablaut. But, as a matter of fact, the verbs of the fifth, sixth and seventh class do not employ ablaut in past participle formation at all, participles showing the base forms of the stems. It must be recognised that the primary forms of a German strong verb stem mostly include just one ablaut form; only stems of the third and fourth class have two of them.

The form-function-relation found with ablaut in German is straightforward and rigid: this is the pay-off of a strictly 'surfacist' approach to morphology. Its surface orientation sets the present analysis apart from those approaches that try to grasp ablaut in terms of rules that apply to 'underlying' forms. Taking recourse to underlying forms only clouds the actual regularities. $^{44}$

A further study of the foundations on which ablaut is built would surely be worthwhile. Here I confine myself to pointing to the rôle of iconicity as a basis for quantitative ablaut. Change of quantity type that produces forms of normalised length is used as a component of simple ablaut, which has the rather unspecific functional value of general past marking. On the other hand, change of quantity type that produces forms of marked length is used as a component of full ablaut, which has the more specific functional value of finite past marking. The diagrammatic correspondence between form and function is patent. The preference for bases in front vowels as opposed to ablaut forms in back vowels is another iconic aspect of ablaut, which, however, I cannot go into here. ${ }^{45}$

\section{Inflectional classes}

\subsection{Ablaut classes}

The traditional division of strong verb classes, each distinguished by a particular overall ablaut pattern, is not an antiquated descriptive tool of nineteenth century linguistics; nor is its relevance restricted to diachronic matters or to

\footnotetext{
${ }^{44}$ Ségéral \& Scheer freely use non-surface 'lexical' forms (cf. note 12, supra) in order to defend their claim that German gradations are instantiations of a certain, allegedly universal pattern (the 'apophonic path'). But even so, by their own count, only 59 percent of German strong verbs fit into the scheme; the remaining ones are, in their terms, only 'halfapophonic' or even 'non-apophonic'.

${ }^{45}$ For some hints see already Adelung (1782: 785 et passim); cf. Tanz (1971: 269) and Plank (1979: 144-145) with reference to English, and see Stedje (1987) on 'mentalistic theories' of ablaut. On iconicity of quantitative ablaut see also Mayerthaler (1981: Section 5.2.3) with reference to Gothic.
} 
older forms of German or Germanic. Rather, it is particularly appropriate to the system of strong verbs of Contemporary Standard German - in spite of widely accepted claims to the contrary. This, too, may be read off Table 5. A division that is very close to the traditional one arises from a strictly synchronic analysis of the ablaut system when stem lexemes are classified according to the types of alternations exhibited by their forms (cf. also Fourquet 1970: 61). Only, the division is simplified in Contemporary German since the historical third class and the historical fourth class have become one as regards qualitative ablaut.

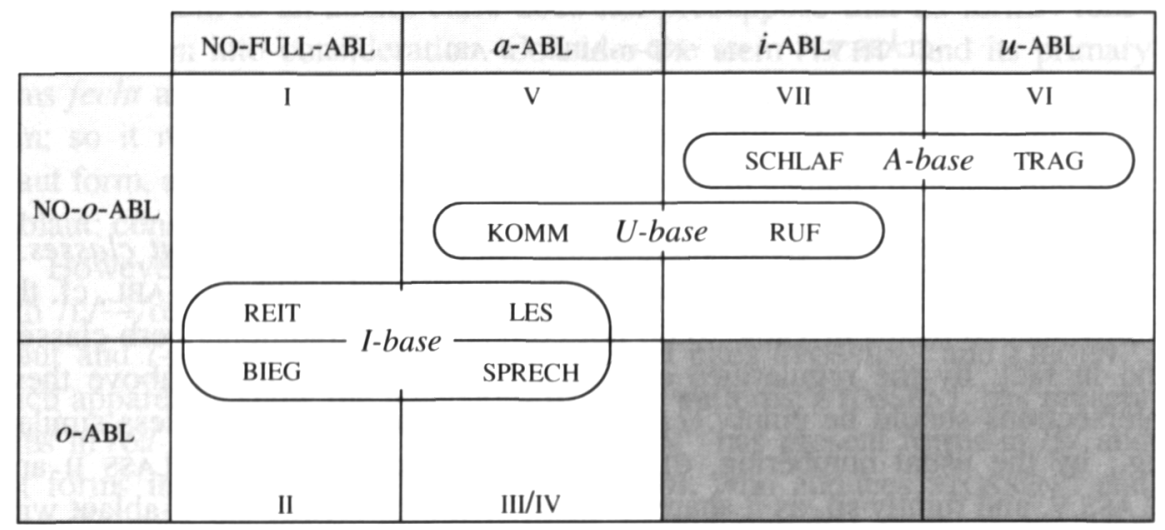

Table 6. Stem lexemes: ablaut classes

As the above analysis has revealed, change of quality type is a fundamental of ablaut in German; two types have been distinguished: full ablaut (comprising $i$-ablaut $/ a$-ablaut $/ u$-ablaut) and $o$-ablaut (a variety of simple ablaut). Accordingly, stems may be classified into those that show both $o$-ablaut and full ablaut (cf. SPRECH ${ }^{\mathrm{L}}$ ), only the one or the other $\left(\mathrm{cf}\right.$. LES ${ }^{\mathrm{L}}$ and $\mathrm{BIEG}^{\mathrm{L}}$ ) or neither (cf. REIT ${ }^{\mathrm{L}}$, which has $i$-monophthongisation, a second variety of simple ablaut). (In addition, there are a few stems with diphthongal bases that show $o$-ablaut or $i$-ablaut but no change of quality type, cf. Section 2.6.)

I assume, then, a cross-classification on the set of strong verb stem lexemes based on two criteria, viz. 'o-ablaut: yes/no' and 'full ablaut: yes/no' (in the affirmative case: $i-, a$ - or $u$-ablaut). As full ablaut has three subtypes, the system allows eight types of stems, as illustrated in Table 6 . The rows represent the classification according to $o$-ablaut; the columns represent the classification according to full ablaut. The heads of rows and columns introduce names for the classes that are distinguished; for instance, $o$-ABL is the set of verb stems that exhibit $o$-ablaut - an alternation pattern identified in Sec- 
tion 2. Names of example lexemes are put into the boxes; the quality types to which the pertinent bases regularly belong are noted.

The cross-classification provides six stem classes that correspond to traditional classes of strong verbs (as indicated by the Roman numerals that are put into the boxes). Formally, these stem classes are identified as the following intersections of classes:

$\begin{array}{lll}\text { CLASS I } & = & \text { NO- } o-\mathrm{ABL} \cap \mathrm{NO}-\mathrm{FULL}-\mathrm{ABL} \\ \text { CLASS II } & =_{\mathrm{df}} & o-\mathrm{ABL} \cap \mathrm{NO}-\mathrm{FULL}-\mathrm{ABL} \\ \text { CLASS III/IV } & =_{\mathrm{df}} & o-\mathrm{ABL} \cap a-\mathrm{ABL} \\ \text { CLASS V } & ==_{\mathrm{df}} & \text { NO- } o-\mathrm{ABL} \cap a \text {-ABL } \\ \text { CLASS VI } & ==_{\mathrm{df}} & \text { NO- } o-\mathrm{ABL} \cap u \text {-ABL } \\ \text { CLASS VII } & = & \text { NO- } o-\mathrm{ABL} \cap i \text {-ABL }\end{array}$

The defined classes of stem lexemes will be referred to as ablaut classes. ${ }^{46}$ The two combinations that remain $(o-\mathrm{ABL} \cap i$-ABL and $o$-ABL $\cap u$-ABL, cf. the darkly shaded boxes in Table 6) do not correspond to traditional verb classes, and in fact, by the regularities of ablaut in German discussed above these intersections should be empty. ${ }^{47}$ Ablaut classes may be more or less similar; e.g., by the usual numbering, CLASS III/IV is placed between CLASS II and CLASS V, and rightly so, as it shares $o$-ablaut with the former and $a$-ablaut with the latter. Since ablaut classes are introduced as derived classes, their (dis-)similarities are accounted for in a straightforward manner.

The apparent diversity of present stem vocalism as well as particularities of 'present stem formation' should not detract from the high degree of regularity of ablaut patterns. Quite generally, inflectional classes are to be defined in terms of the formation of derived forms, not in terms of the make-up of base

\footnotetext{
${ }^{46}$ In addition, minor classes may be identified if necessary: for instance, CLASS III and CLASS IV are subclasses of CLASS III/IV. CLASS III stems have short, sonorant I-bases (cf. Section 2.5, supra); these stems have /a/-ablaut forms. CLASS IV comprises the remaining bases; these stems have /a:/-ablaut forms. Similarly, CLASS VII may be divided into CLASS VIIb (stems that have U-bases) and CLASS VIIa (the remaining ones), cf. Paul (1989: 251). Classes of verbs may be introduced as derived classes (Lieb 1983: 173); a verb of the first class of strong verbs is a verb the stem of which belongs to CLASS I etc.

${ }^{47}$ The first 'case vide' $(o$-ABL $\cap i$-ABL) is indeed empty. $o$-ablaut as a rule requires monophthongal I-bases, which, in German, do not permit $i$-ablaut. $o$-ABL $\cap u$-ABL should be empty, too, since in German distinct ablaut forms ordinarily belong to distinct quality types. However, if $S C H W O \mathrm{R}^{\mathrm{L}}$ and perhaps $\mathrm{ANHEB}^{\mathrm{L}}$ are exceptions to this rule (cf. Section 2.7), then they belong here; though exceptional, gradations involving both $o$-ablaut and $u$-ablaut would not break the system.
} 
forms (Wurzel 1984b: 68). Ablaut classes make no exception, pace Hook (1968) and others.

\subsection{Ablaut class membership}

Statements that assign stems to ablaut classes may be understood as elementary characterisations. From this vantage point, the stem SPRECH ${ }^{\mathrm{L}}$ has the ablaut forms sproch and sprach because it belongs to CLASS III/IV. On the other hand, knowledge of a stem's primary forms is usually sufficient to determine its ablaut class even if their functional types are not given: as a rule, assigning a stem to an ablaut class does not presuppose that its forms' functions are taken into consideration. Consider the stem $\mathrm{FECHT}^{\mathrm{L}}$ and its primary forms fecht and focht. On account of its vowel, fecht is not a possible ablaut form; so it must be a base form, and consequently, the $o$-form focht is an ablaut form, and the only one at that. Thus this stem exhibits $o$-ablaut and only $o$-ablaut; consequently it belongs to CLASS II.

However, Wurzel (1984a: 661) points to cases of 'inverse alternations'. Both $/ \mathrm{i}: / \rightarrow / \mathrm{o}: /$ and $/ \mathrm{a}: / \rightarrow / \mathrm{i}: /$ are inconspicuous alternations (viz. cases of $o$ ablaut and $i$-ablaut, respectively), but Wurzel cites STOSSEN ${ }^{\mathrm{w}}$ and LIEGEN ${ }^{\mathrm{W}}$, which apparently show the inversions of these patterns: $\operatorname{STOSSEN}^{\mathrm{W}}$ has present forms in /o:/ and past forms in /i:/ and LIEGEN ${ }^{\mathrm{W}}$ has present forms in /i:/ and past forms in /a:/. Richard Wiese (1996: 130), who adduces STOSSEN ${ }^{\mathrm{W}}$ and BIETEN $^{\mathrm{W}}$, even maintains that "all types of bidirectional relations between vowels" are to be found with ablaut in German. As Table 5 shows this is not the case. As a rule, ablaut patterns are not reversible. The examples to prove the opposite are not typical, to say the least.

As for LIEG $^{\mathrm{L}}$, by the above account (which adapts a proposal of Wurzel 1970: 77), ablaut proceeds on the basis of leg (giving lag by /e:/ $\rightarrow$ a:/alternation) while lieg is due to (exceptional) e/i-alternation. Whatever analysis is espoused, LIEG $^{\mathrm{L}}$ shows aberrant present tense formation and is, at best, an exception but does not provide evidence for arbitrary inversions of ablaut. The comparison of BIET $^{\mathrm{L}}$ and $\mathrm{STOSS}^{\mathrm{L}}$ also draws on rather peripheral cases. (STOSS $^{\mathrm{L}}$ is the only stem that has an $o$-base and an $i$-ablaut form; on BIET $^{\mathrm{L}}$ see note 25, supra.) Even if these exceptions stand up to scrutiny, it is significant that it holds good (at least for the overwhelming majority of strong verb stems, allowing for one or two exceptions, if any): given a stem's primary forms, its ablaut class is fixed, that is, only expression-related properties of stem forms have to be resorted to in order to determine a stem's ablaut class. 


\subsection{Ablaut class markedness}

In the majority of cases knowledge of the base form alone suffices to determine to which ablaut class a stem belongs. Usually, there are two or at most three classes that have to be taken into account. Let me refer to stems that have I-bases as I-base stems, to stems that have not as non-I-base stems. Similarly, I will use the terms A-base stem and U-base stem. Now consider stems with monophthongal bases: I-base stems belong to CLASS II, III/IV, or V; A-base stems belong to CLASS VI or VII, and U-base stems belong to CLASS V or VII (cf. Table 6). Stems with diphthongal I-bases belong to CLASS I; only one /ai/-base stem is in CLASS VII. Stems with diphthongal U-bases belong to CLASS II or CLASS VII. These assignments derive from the general formal characteristics of ablaut in German, which have been discussed in Section 2.

Moreover, the ablaut classes to be considered are not of the same rank. They differ with respect to inflectional class markedness (Wurzel 1989; cf. also Durrell 2001). With I-base stems, the major division is whether $a$-ablaut is applicable or not. Membership in $a$-ABL is the marked option. Note that:

- The majority of I-base stems do not show $a$-ablaut; they belong to NOFULL-ABL and thus to CLASS I or II according as the base is diphthongal or monophthongal.

- The internal variability of the class NO-FULL-ABL is much greater than that of the class $a$-ABL. $a$-ablaut is not found with bases that show "conspicuous' vocalism, to wit, (i) with diphthongal bases, (ii) with bases in rounded front vowels, or (iii) with bases that have long vowels before voiceless consonants (other than $/ \mathrm{t} /$ ). But all types of front vowels that occur in bases of strong verb stems at all appear in bases of NO-FULL-ABL stems, cf. $\operatorname{BIEG}^{\mathrm{L}}(/ \mathrm{i}: /), \operatorname{SCHIND}^{\mathrm{L}}(/ \mathrm{I} /), \operatorname{HEB}^{\mathrm{L}}(/ \mathrm{e}: /), \operatorname{FECHT}^{\mathrm{L}}(/ \varepsilon /), \mathrm{GÄR}^{\mathrm{L}}(/ \varepsilon: /)$,

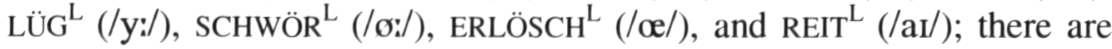
no bases in $/ \mathrm{Y} /$ or $/ \mathrm{oI} /$. On the other hand, if I-base stems show $a$-ablaut, the base vowel is $i$ or $e^{48}$

- A considerable number of stems have abandoned $a$-ABL for NO-FULLABL.

An argument against the unmarked status of NO-FULL-ABL might be based on the fact that it is only CLASS III/IV stems that take advantage of the full potential of form differentiation. Only these stems show double ablaut (that is, simple and full ablaut): only these stems employ two distinct ablaut alterna-

\footnotetext{
${ }^{48}$ It is $i$ if, and only if, it is short and followed by a nasal (thus $/ \mathrm{I} /$ ). Otherwise it is $e$ (i.e., $/$ e:/ or $/ \varepsilon /$ ); in addition there is one $/ \varepsilon: /$-base stem $\left(\right.$ GEBÄR $\left.^{\mathrm{L}}\right)$. For SITZ ${ }^{\mathrm{L}}$, BITT ${ }^{\mathrm{L}}$, and $\mathrm{LIEG}^{\mathrm{L}}$, cf. Section 2.7 .
} 
tions in forming 'past participle stems' and 'primary past stems', respectively. But then having this property means not to conform to the pattern of stem form distinctions found with weak verbs (whereas the unmarked status of NO-FULLABL is confirmed as it is precisely the stems in this class that follow the model of the productive, weak class in as far as they do not show a distinction between 'past participle stems' and 'primary past stems').

As regards non-I-base stems, by similar considerations the unmarked option is $i$-ablaut (i.e., membership in CLASS VII, cf. Wurzel 1970: 79) while $u$-ablaut or, again, $a$-ablaut are the marked options. The majority of non-I-base stems belong to CLASS VII; as regards $u$-ablaut, there are rigid restrictions on the make-up of the bases that will be noted below.

I take it, then, that membership in NO-FULL-ABL and in $i$-ABL are the standard (unmarked or 'default') options for I-base stems and non-I-base stems, respectively. Thus, in order to determine ablaut class membership all that has to be done is to single out those stems that take the marked option. But, membership in non-default-classes is subject to rather restrictive conditions. The majority of stems that meet these conditions do belong to these classes indeed; only minority groups belong to one of the default-classes nevertheless, and it is only the latter groups that set bounds to an attempt to derive ablaut class membership from the make-up of bases.

\subsection{I-base stems and ablaut classes}

In the unmarked case, I-base stems belong to NO-FULL-ABL. The marked option is to have $a$-ablaut. It is true, there are two subclasses of NO-FULL-ABL (CLASS I and CLASS II) but the division in terms of the diphthongalmonophthongal-distinction is straightforward. All /az/-, /i:/-, /y:/-, /ø:/-, and $/ œ /$-base stems are in NO-FULL-ABL (except HEISS ${ }^{\mathrm{L}}$, CLASS VII); these are: ${ }^{49}$

- /aI/-bases, CLASS I:

SCHEIN $^{\mathrm{L}},($ ER/VER $)$ BLEICH $^{\mathrm{L}}$, GLEICH $^{\mathrm{L}}$, STREICH $^{\mathrm{L}}$, WEICH $^{\mathrm{L}}$, SCHLEICH $^{\mathrm{L}}$,

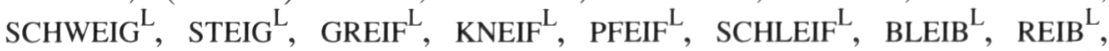
SCHREIB $^{\mathrm{L}}$, TREIB $^{\mathrm{L}}$, PREIS ${ }^{\mathrm{L}}$, WEIS ${ }^{\mathrm{L}}$, BEISS $^{\mathrm{L}}$, REISS $^{\mathrm{L}}$, SCHEISS $^{\mathrm{L}}$, SCHMEISS $^{\mathrm{L}}$,

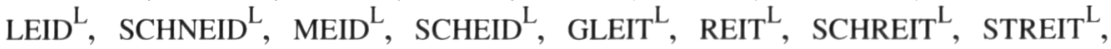
GEDEIH $^{\mathrm{L}}$, LEIH $^{\mathrm{L}}$, SCHREI $^{\mathrm{L}}$, SPEI $^{\mathrm{L}}$, ZEIH $^{\mathrm{L}}$

\footnotetext{
${ }^{49}$ The following lists cannot be definite as there are a few borderline cases. With a number of verbs, judgements concerning acceptability of strong forms do not coincide, cf. (BE)DING ${ }^{\mathrm{L}}, \mathrm{KÜR}^{\mathrm{L}} /(\mathrm{ER}) \mathrm{KIES}^{\mathrm{L}}$, MELK $^{\mathrm{L}}, \mathrm{SCHLEISS}^{\mathrm{L}}$, SPLEISS $^{\mathrm{L}}$; see reference grammars for details, e.g., Curme (1924: 300-315); cf. also Aldenhoff (1961). However, even these peripheral cases, if included, fit into the classes as characterised in the text.
} 
- /i:/-, /y:/-, /ø:/-, or /œ/-bases, CLASS II:

FRIER $^{\mathrm{L}}$, VERLIER ${ }^{\mathrm{L}}, \mathrm{KRIECH}^{\mathrm{L}}, \mathrm{RIECH}^{\mathrm{L}}, \mathrm{BIEG}^{\mathrm{L}}$, FLIEG $^{\mathrm{L}}$, WIEG $^{\mathrm{L}}, \mathrm{TRIEF}^{\mathrm{L}}$, SCHIEB $^{\mathrm{L}}$, STIEB ${ }^{\mathrm{L}}$, FLIESS $^{\mathrm{L}}$, GENIESS $^{\mathrm{L}}$, GIESS $^{\mathrm{L}}$, SCHLIESS $^{\mathrm{L}}$, SCHIESS ${ }^{\mathrm{L}}$, SPRIESS $^{\mathrm{L}}$, VERDRIESS $^{\mathrm{L}}$, SIED $^{\mathrm{L}}$, BIET $^{\mathrm{L}}$, FLIEH $^{\mathrm{L}}$, ZIEH $^{\mathrm{L}}$, LÜG $^{\mathrm{L}}$, TRÜG $^{\mathrm{L}}$, SCHWÖR ${ }^{\mathrm{L}}$, VER/ERLÖSCH ${ }^{\mathrm{L}}$

The remaining I-base stems (viz. stems with bases in /e:/, / $\varepsilon: /, / \varepsilon /$, or /I/) usually have $a$-ablaut. The majority belong to CLASS III/IV, that is, they show $a$-ablaut and $o$-ablaut; a minority have $a$-ablaut but lack $o$-ablaut (that is, they are in CLASS v). The distribution is controlled by both the quantity type and the consonantism of the base. Two classes may be singled out: sonorant bases, the segment immediately following the vowel is a sonorant, and s-bases, the segment immediately following the vowel is an alveolar fricative (i.e., $/ \mathrm{s} /$ or $/ \mathrm{z} /$ ). Given that an I-base stem has $a$-ablaut (thus is a member of $a-\mathrm{ABL})$ and given the consonantal structure of its base, its ablaut class is fixed as shown in Table 7.

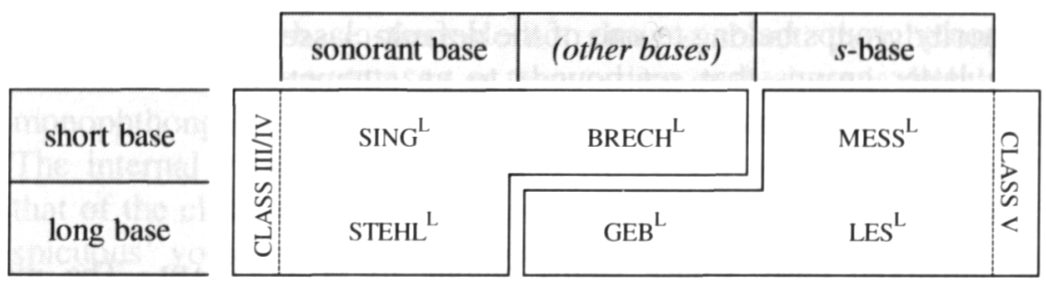

Table 7. $a$-ablaut stems

with $o$-ablaut (CLASS III/IV) and without $o$-ablaut (CLASS V)

Members of $a$-ABL with short bases have $o$-ablaut (with the exception of $s$ base stems); members of $a$-ABL with long bases do not have $o$-ablaut (with the exception of sonorant base stems).

Evidently, stems of CLASS III/IV and CLASS $\mathrm{V}$ are rather different as regards their vocalic and consonantal structure, cf.:

- short I-base stems, CLASS III/IV:

SINK $^{\mathrm{L}}$, TRINK $^{\mathrm{L}}$, STINK $^{\mathrm{L}}, \mathrm{SING}^{\mathrm{L}}$, RING $^{\mathrm{L}}$, DRING $^{\mathrm{L}}$, WRING $^{\mathrm{L}}$, SPRING $^{\mathrm{L}}, \mathrm{GE} / \mathrm{MISS}-$

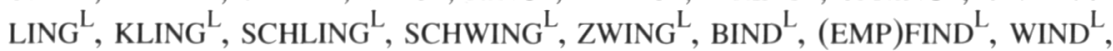
$\mathrm{SCHWIND}^{\mathrm{L}}, \mathrm{SINN}^{\mathrm{L}}$, SPINN $^{\mathrm{L}}$, RINN $^{\mathrm{L}}$, GEWINN $^{\mathrm{L}}$, BEGINN $^{\mathrm{L}}, \mathrm{SCHWIMM}^{\mathrm{L}}$, SCHELT $^{\mathrm{L}}$, GELT ${ }^{\mathrm{L}}$, HELF $^{\mathrm{L}}$, BERST ${ }^{\mathrm{L}}$, BERG ${ }^{\mathrm{L}}$, VERDERB $^{\mathrm{L}}$, WERB $^{\mathrm{L}}$, STERB ${ }^{\mathrm{L}}$, WERF $^{\mathrm{L}}, \mathrm{BRECH}^{\mathrm{L}}, \mathrm{SPRECH}^{\mathrm{L}}$, ERSCHRECK ${ }^{\mathrm{L}}$, TREFF $^{\mathrm{L}}, \mathrm{STECH}^{\mathrm{L}}$

- long I-base stems, CLASS III/IV:

BE/EMPFEHL ${ }^{\mathrm{L}}$, STEHL ${ }^{\mathrm{L}}$, GEBÄR ${ }^{\mathrm{L}}, \mathrm{NEHM}^{\mathrm{L}}$ 
- short I-base stems, CLASS v: ${ }^{50}$

ESS $^{\mathrm{L}}$, FRESS $^{\mathrm{L}}$, MESS $^{\mathrm{L}}$, VERGESS $^{\mathrm{L}}$, SITZ $^{\mathrm{L}}$

- long I-base stems, CLASS v:

$\mathrm{SEH}^{\mathrm{L}}, \mathrm{GESCHEH}^{\mathrm{L}}$, LES $^{\mathrm{L}}$, GENES $^{\mathrm{L}}$, BITT $^{\mathrm{L}}$, TRET $^{\mathrm{L}}, \mathrm{LIEG}^{\mathrm{L}}, \mathrm{GEB}^{\mathrm{L}}$

Finally, there are a number of stems that have bases in /e:/, /ع:/, / $/ \varepsilon /$ or $/ \mathrm{I} /$ and thus would 'qualify' for $a$-ablaut as regards their base vowels but which are in CLASS II nevertheless:

- /e:/-, / $\varepsilon: /-, / \varepsilon /-$, or /I/-bases, CLASS II:

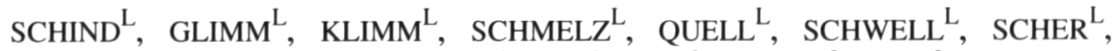

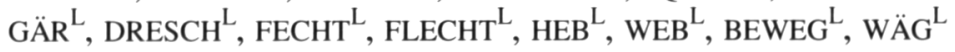

Even membership in this special group is not random, but a detailed discussion would be beyond the scope of this paper. Suffice it to note that there are at least two relevant factors: ${ }^{51}$

(i) 'Family resemblance'. I-base stems are invariably in CLASS III/IV if the vowel is followed by a velar nasal. Stems of this type (e.g., $\operatorname{SING}^{\mathrm{L}}$, TRINK $^{\mathrm{L}}$ ) are, then, among the 'best exemplars' of this class. ${ }^{52}$ On the other hand, it is a sufficient condition for membership in CLASS $\mathrm{v}$ for a stem to have an $e$-base such that the vowel is followed by nothing but an alveolar obstruent (if anything); thus LES ${ }^{\mathrm{L}}$ is a 'prototypical' member of CLASS V. The tendency to leave CLASS III/IV or CLASS V is the stronger the less prominent the family resemblance to the best exemplars of those classes is. ${ }^{53}$

(ii) 'Phonotactic en-/discouragement'. Consider $\mathrm{WIEG}^{\mathrm{L}} / \mathrm{WÄG}^{\mathrm{L}} / \mathrm{BEWEG}^{\mathrm{L}}$ and $\mathrm{WEB}^{\mathrm{L}}$, which come from CLASS V. It is assumed that these stems developed $o$-forms under the influence of the initial /v/ (Paul 1917: 230); moreover, they lost $a$-ablaut and are now in CLASS II (in as far as strong

\footnotetext{
${ }^{50}$ The bases of SITZ $^{\mathrm{L}}$, LIEG $^{\mathrm{L}}$ AND BITT ${ }^{\mathrm{L}}$ are sess /zes/, leg /le:g/ and bet /be:t/, respectively (cf. Section 2.7).

${ }^{51}$ Another possible factor is confusion with weak causatives (Paul 1917: 219).

${ }^{52}$ See the analysis by Bybee \& Slobin (1982) of the cognate class in English for a discussion of the rôle of prototypes, schemes and family resemblance; cf. also Bybee \& Moder (1983) and Köpcke (1999).

${ }^{53}$ This applies to stems without a post-vocalic sonorant (e.g., FLECHT ${ }^{\perp}$, FECHT $^{\perp}$, DRESCH $^{L}$ ) that have left CLASS III/IV and to stems ending in non-alveolar obstruents that have left CLASS V (e.g., BEWEG ${ }^{\mathrm{L}}$, WEB ${ }^{\mathrm{L}}$ ), thus stems with 'other bases' by the classification presented in Table 7.
} 
forms are still in use). The vowel occurs in a context that favours rounded vowels (Paul 1989: 78); presumably, such a context may encourage $o$-ablaut and may discourage $a$-ablaut (in particular when $/ 0 /-$ and $/ a /-$ forms compete). Similar remarks may apply to most of the other stems that have lost $a$-ablaut; e.g., those where the vowel appears side by side with $/ \mathrm{S} /$. The largest group of apostates comprises SCHMELZ ${ }^{\mathrm{L}}$, QUELL ${ }^{\mathrm{L}}$, $\mathrm{SCHWELL}^{\mathrm{L}}$, GLIMM ${ }^{\mathrm{L}}$, and $\mathrm{KLIMM}^{\mathrm{L}}$, the bases being schmelz/Smelts/, quell $/ \mathrm{kv \varepsilon l} /$, schwell $/ \mathrm{sv \varepsilon l} /$, glimm $/ \mathrm{glim} /$, and $\mathrm{klimm} / \mathrm{klim} /$, respectively; cf. also MELK ${ }^{\mathrm{L}}$, melk /melk/. In these bases, the vowels occur between a voiced labial $(/ \mathrm{v} /$ or $/ \mathrm{m} /)$ on the one hand and a lateral (/l/) on the other; no such stem allows $a$-ablaut in Contemporary German. Bases with initial labial+lateral-cluster (FLECHT ${ }^{\mathrm{L}}$; PFLEG $^{\mathrm{L}}$, strong forms now obsolete) belong here, too. ${ }^{54}$

Summing up, the unmarked option for I-base stems is NO-FULL-ABL. However, stems with $e$-bases or short $i$-bases have as a rule $a$-ablaut, though a number of stems that do not fit neatly into $a$-ABL have moved into NO-FULL-ABL, adopting the unmarked option. I-base stems that have $a$-ablaut belong either to CLASS III/IV ( $a$-ablaut and $o$-ablaut) or to CLASS V (only $a$-ablaut); membership is determined in terms of the quantity types and the consonantal structures of the bases.

\subsection{Non-I-base stems and ablaut classes}

As for non-I-base stems, $i$-ablaut is the unmarked option. A-base stems belong to CLASS VII $(i$-ablaut) or CLASS VI ( $u$-ablaut):

- A-bases, ClASS VII:

(EMP)FANG ${ }^{\mathrm{L}}, \mathrm{HÄNG}^{\mathrm{L}}, \mathrm{HALT}^{\mathrm{L}}, \mathrm{FALL}^{\mathrm{L}}, \mathrm{SCHLAF}^{\mathrm{L}}, \mathrm{BRAT}^{\mathrm{L}},(\mathrm{GE}) \mathrm{RAT}^{\mathrm{L}}, \mathrm{BLAS}^{\mathrm{L}}$, LASS $^{\mathrm{L}}$

- A-bases, CLASS VI:

WACHS $^{\mathrm{L}}, \mathrm{WASCH}^{\mathrm{L}}, \mathrm{BACK}^{\mathrm{L}}, \mathrm{SCHAFF}^{\mathrm{L}}, \mathrm{SCHLAG}^{\mathrm{L}}, \mathrm{TRAG}^{\mathrm{L}}, \mathrm{GRAB}^{\mathrm{L}}, \mathrm{LAD}^{\mathrm{L}}$, FAHR $^{\mathrm{L}}$

For a stem to be in CLASS VI, its base must meet a severe condition of "normalcy': short vowels must be followed by voiceless consonants, long vowels

\footnotetext{
${ }^{54}$ Cf. Ségéral \& Scheer (1998: 50), who, however, maintain that the verbs in question do have (underlying) $a$-forms in the finite past (which surface as $o$-forms) - an untenable position that mixes up synchrony and diachrony. For an overview of the diachronic development see Solms \& Wegera (1993: 270-278), for details Solms (1984) and Chirita (1988).
} 
must be followed by voiced consonants. (Consequently, ablaut forms due to $u$-ablaut are invariably long.) Moreover, as in the case of CLASS III/IV, $s$-bases are not admitted. Stems are in CLASS VI if, and only if, their bases conform to one of the following two patterns:

$$
\begin{aligned}
& / \mathrm{a} /+ \text { voiceless consonant }(\neq / \mathrm{s} /) \\
& / \mathrm{a} / /+ \text { voiced consonant }(\neq / \mathrm{z} /)
\end{aligned}
$$

The remaining A-base stems are in CLASS VII. (The bases are fang /fan/, hang /hay/, halt /halt/, fall /fal/, schlaf /Sla:f/, brat /bra:t/, rat /ra:t/, blas /bla:z/, and lass /las/, respectively.)

As regards the small set of stems that have monophthongal U-bases, ablaut class membership is straightforward given the above observations on 'conspicuous' vocalism. RUF ${ }^{\mathrm{L}}$ and STOSS $^{\mathrm{L}}$ show marked base vocalism: the vowels are long although followed by voiceless obstruents; they are in CLASS VII (the unmarked option for non-I-base stems). There is only one more U-base stem, namely KOMM ${ }^{\mathrm{L}}$, which is in CLASS v. Likewise, stems with diphthongal U-bases would not qualify for the marked option $a$-ablaut. Two such stems are in CLASS II (SAUF ${ }^{\mathrm{L}}, \mathrm{SAUG}^{\mathrm{L}}$ ), which agrees with the disposition of diphthongal bases not to show change of quality type $;^{55} \mathrm{LAUF}^{\mathrm{L}}$ and $\mathrm{HAU}^{\mathrm{L}}$ show $i$-ablaut as expected in the case of $U$-base stems. The distribution apparently does not correlate with synchronically determinable properties of the stems. ${ }^{56}$

\section{Ablaut: an integrated view}

Any adequate analysis of ablaut should uncover how ablaut contributes to the categorisation of verb forms. Consider, e.g., VERSPRECHEN ${ }^{\mathrm{W}}$ with its forms versprechen (infinitive or 1st/3rd person plural of the present), versprachen (1st/3rd person plural past indicative), and in particular versprochen (past participle). Obviously, it is attributable to the occurrence of the stem form versproch that the verb form versprochen functions as a past participle. To grasp this fact, one might be inclined to resort to functional types of stem forms: versproch is a 'participle stem' and the refore versprochen is a participle form. However, as noted in Section 1.3, supra, an account like this would be liable to circularity. After all, a stem form would qualify as a 'parti-

\footnotetext{
${ }^{55}$ Sometimes SCHNAUBEN ${ }^{\mathrm{W}}$ is mentioned as having a 'poetic' form schnob.

${ }^{56}$ Diachronically, the distribution corresponds to the distinction between 'old diphthongs' and 'new diphthongs' (diphthongs going back to the so-called New High German diphthongisation). Stems with bases in 'new diphthongs' show simple ablaut, stems with bases in 'old diphthongs' show full ablaut (but SCHEID ${ }^{\mathrm{L}}$ has changed classes, cf. note 30 , supra).
} 
ciple stem' only because it occurs in a participle. Furthermore, since ablaut is a relational phenomenon it is, in general, not possible to determine a stem form's membership in a functional category such as 'participle stem' on the basis of its expression related properties alone. A formal determination would have to include reference to properties of stem lexemes. ${ }^{57}$

The present morphological approach avoids a vicious circle, based as it is on morphological categories that are determined in formal (expression-related) terms. The present section will be devoted to a demonstration of how functional categorisations of verb forms relate to formal categorisations of stem forms. To this end I shall fit together the major components of the account of ablaut that have been developed in the preceding. Discussion focuses on a single example, which, however, should suffice to illustrate how the proposed 'item-and-paradigm-model' works.

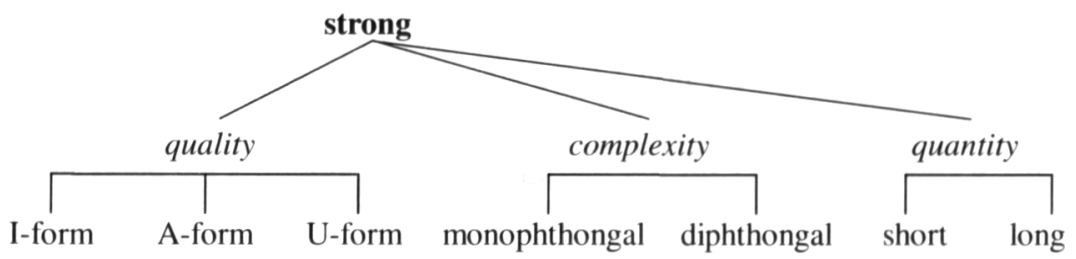

Figure 2. Expression types of forms of stems of strong verbs

In Section 2, I have established a system of classifications of forms of stems (of strong verbs) that is based on the forms' vocalism (cf. Table 2, page 110); it may be represented by means of a classificatory tree as in Figure 2. The basic set strong is the set of forms of stems of strong verbs. There are three simultaneous classifications on strong that supply the expression types (such as I-form etc.) that have been discussed. On this basis, categorisations, i.e., sets of morphological categories, may be assigned to stem forms. The primary forms of the stem lexeme VERSPRECH ${ }^{\mathrm{L}}$ are categorised as follows:

$\langle$ versprech, $\{\mathrm{I}$-form, monophthongal, short, ... $\}\rangle$
$\langle$ versproch, $\{\mathrm{U}$-form, monophthongal, short, ... $\}\rangle$
$\langle$ versprach, $\{\mathrm{A}$-form, monophthongal, long, ... $\}\rangle$

\footnotetext{
${ }^{57}$ For example, the set of stem forms that occur in participles of strong verbs is the union of (i) the set of ablaut forms of stems of CLASS I, (ii) the set of $o$-ablaut forms, and (iii) the set of base forms of stems of CLASS V, VI, and VII. This complex roundabout identification presupposes both the classification systems for stem forms and for stem lexemes. Similarly, the class of 'past stems' could not be construed as a 'pure form class' (in the sense of Blevins 2003): there is more than one 'form class' that includes 'past stems'.
} 
These are three pairs of morphological units and sets of categories that contain the respective units. The morphological paradigm of the stem VERSPRECH ${ }^{\mathrm{L}}$ is a set of such pairs. To complete the paradigm, pairs that account for 'secondary stems' would have to be added; the classification system would have to be extended in order to take care of their specific characteristics. Hence additional categories would have to be incorporated into the categorisations as indicated by the dots. As these are not relevant to ablaut, they have been omitted.

In Section 4, I have established a system of classifications of stem lexemes of strong verbs that is based on the types of alternations among stem forms (cf. Table 6, page 133); it may be represented by means of a classificatory tree as in Figure $3 .^{58}$ The basic set STRONG is the set of stem lexemes of strong verbs. There are two simultaneous classifications on STRONG that supply the classes (such as $o$-ABL, etc.) on which ablaut classes (CLASS I, etc.) are based. The example stem VERSPRECH ${ }^{\mathrm{L}}$ belongs to the classes $o$-ABL and $a$-ABL and thus, by definition, to CLASS III/IV. The set $\{o-\mathrm{ABL}, a-\mathrm{ABL}, \ldots\}$ provides a morphological characterisation of the stem VERSPRECH ${ }^{\mathrm{L}}$.

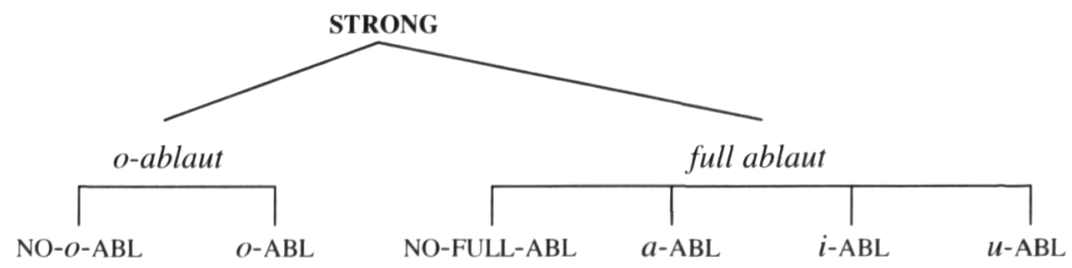

Figure 3. Types of stem lexemes of strong verbs

Derivatively, the characterisation of the stem VERSPRECH ${ }^{\mathrm{L}}$ also provides for a characterisation of its forms. As VERSPRECH ${ }^{\mathrm{L}}$ is a stem of CLASS III/IV, so versproch is a form of a stem of CLASS III/IV. There are, then, two sets of categories that have to be taken into account to obtain a complete morphological characterisation of the stem form versproch, viz. (i) the set of categories that it is contained in (viz. $\{\mathrm{U}$-form, monophthongal, short, ...\}) and (ii) the set of categories that the lexeme of which it is a form is contained in (viz. $\{0-\mathrm{ABL}$, $a-\mathrm{ABL}, \ldots\})$. The pair of these sets provides the starting point for determining

\footnotetext{
${ }^{58}$ The classification systems displayed in figures 2 and 3 are assumed to be part of the morphological unit ordering of German idiolect systems and the lexeme ordering of German idiolect systems, respectively (cf. Lieb 1983: 168, 171).
} 
the functional contribution of the stem form versproch to the verb form versprochen: ${ }^{.9}$

$\langle\{\mathrm{U}$-form, monophthongal, short, $\ldots\},\{o-\mathrm{ABL}, a-\mathrm{ABL}, \ldots\}\rangle$

All in all, versproch is characterised as a short, monophthongal U-form of a stem lexeme that exhibits both $o$-ablaut and $a$-ablaut. All the categories involved are defined in formal (expression related) terms. Now consider versproch as it occurs in versprochen. Given the above findings on the formfunction-relation, the (formal) morphological characterisation of the stem form is sufficient to determine the (functional) categorisation of the verb form versprochen (which is a past participle). This may be shown as follows. ${ }^{60}$

(i) As has been established in Section 3, simple ablaut serves to mark past forms, full ablaut serves to mark finite past forms.

(ii) versproch is characterised as a U-form and also as a form of a lexeme that belongs to $o$-ABL (a class of stem lexemes) and to CLASS III/IV in particular. It follows that versproch is an ablaut form (and not a base form) and, moreover, that it is an $o$-ablaut form.

(iii) From (i) and (ii) it follows that versprochen is a past form.

(iv) versproch is characterised as a form of a lexeme that belongs to $a$-ABL (a class of stem lexemes). This means that the stem lexeme of which versproch is a form has an $a$-ablaut form as well. By (i), ablaut forms that exhibit $a$-ablaut (thus full ablaut) serve to mark finite past forms. Moreover, because of the priority of more specific markers, the finite past forms of the verb of which versprochen is a form cannot fail to show the specific marker (viz. $a$-ablaut). It follows that the stem form versproch is prevented from occurring in finite past forms.

(v) From (iii) and (iv) it follows that, due to the occurrence of versproch, the verb form versprochen qualifies as a non-finite past form, which is to say, as a past participle.

\footnotetext{
${ }^{59}$ Such pairs (or rather sets containing such pairs) are called morphological markings by Lieb (1983: 179).

${ }^{60}$ A discussion of the theoretical status of form-function-relations is well beyond the scope of the present paper. It may be suggested, however, that in inflectional morphology 'interpretative functions' associated with morphological functions should be recognised (analogous to semantic functions associated with morphological functions in derivational morphology, Lieb 1983: 241). For a different approach see Lieb (1992); Lieb accounts for form-function-relations by means of 'system links' ("Systemverbindungen") between expression-related and functional systems of morphological categories and in addition between expression-related and functional systems of syntactic categories.
} 


\section{Conclusion}

Ablaut has been apostrophised as "one of the classic chestnuts of morphological analysis" (Anderson 1988: 157); certainly, ablaut — and, more generally, 'internal inflection' - has turned out to be a hard nut to crack for many a morphological theory. However, an analysis based on an item-and-paradigmmodel may go a long way towards overcoming those problems that have hampered earlier analyses. In this paper, I hope to have shown that the model's application to ablaut in German turns out to be rewarding.

Many studies of ablaut in German have focused on the question of how the forms of a strong verb can be derived if a certain distinguished (basic) form (usually the infinitive) is given. But again and again, the outcome of such attempts has been found to be unsatisfactory (for critical retrospect see Augst 1975, and, most recently, Köpcke 1999). Since attempts at providing a systematic account of ablaut failed, the contention won ground that there is no system of ablaut in Modern German. Negative results may partly be blamed on the theoretical approaches that have been employed, but also partly, on the way the task to be accomplished had been construed.

For languages like German, it is in general not possible to 'predict' the inflectional forms of a word given only its base form. As regards nouns, dictionaries have to add information on declension class membership (as well as on gender) notwithstanding the fact that the make-up of a word's base form may sometimes provide more or less reliable hints as to what inflectional class the word belongs to. But by no means does it follow that there are no regularities underlying the formation of inflectional forms (cf. B. Wiese 2000). The situation found with verbs, and with strong verbs in particular, is not basically different. Accordingly, the present account proposes a system of six inflectional classes ('ablaut classes', CLASSES I, II, III/IV, V, VI, VII) that reconstructs the traditional system of gradation classes but is defined on a purely synchronic basis.

If there is something special about strong verb stems' membership in inflectional classes, then it is the high degree to which membership is predictable indeed on the basis of expression-related properties of base forms alone. There are general principles of ablaut in Contemporary Standard German (in a nutshell: ablaut is change of quality type or complexity type) that impose heavy restrictions on the selection of ablaut classes. Furthermore, considerations of inflectional class markedness permit it to single out what is the unmarked option given a stem's base (thus to establish a stem's 'default ablaut class'); membership in non-default-classes is subject to rigorous restrictions, 
and the stems that belong there invariably show bases of a characteristic make-up. $^{61}$

What may be more of a surprise are the rigid principles of ablaut that show when alternation types and their functional values are inspected: there is simple ablaut (including $o$-ablaut and $i$-monophthongisation) and there is full ablaut ( $i$-ablaut $/ u$-ablaut $/ a$-ablaut). Simple ablaut and only simple ablaut serves as a general past marker; full ablaut and only full ablaut serves as a special finite past marker. There are no exceptions to this correlation. The findings presented in detail in the body of this paper need not be repeated (cf. Table 5 for a graphic illustration). But assume it were true that, in ablaut alternations, vowels change more or less arbitrarily, as has been claimed so often in the literature. For instance, as there is a gradation $/ \mathrm{i}: / / \mathrm{J} /-/ \mathrm{o} /$ (kriechen-krochgekrochen), what about a (fictitious) gradation $/ \mathrm{i} / / / \mathrm{J} /-/ \mathrm{i} / /$ ? As there is a gradation $/ \varepsilon /-/ a: /-/ 0 /$ (sprechen-sprach-gesprochen), what about such (fictitious) gradations as, say, $/ \varepsilon /-/ \mathrm{o} /-/ \mathrm{a}: /$, or $/ \varepsilon /-/ \mathrm{a} /-/ \mathrm{o} / /$, or $/ \mathrm{e}: / / \mathrm{a} /-/ \mathrm{o} /$ ? Are all of these 'possible gradations' in German? I would argue that there are countless nonexistent gradations that are not missing by chance but would break the system of ablaut in German. As for the exclusion of the above counterfactual examples, it should now be easy to point out what it is that makes them impossible. $^{62}$

Rigidity of ablaut regularities may come as a surprise, mainly because it is common knowledge that original gradations have been deranged, disintegrated or even destroyed by a multitude of diachronic developments, sound changes in particular; and of course, these diachronic facts cannot be denied. On the other hand, opposite compensating and reorganising developments such as Early New High German ablaut levelling, to name but one, are also well known (cf. Augst 1975, Born 1980, Chirita 1988). Thus it would be a mistake to assume that synchronic regularities are mere remnants of a once well-behaved system. From a morphological perspective the opposite view would seem to be nearer to the truth. This is not the place to go into the diachrony of ablaut, but, given the results of the present synchronic analysis, I

\footnotetext{
${ }^{61}$ For details see Section 4, supra. The 'default-classes' are CLASS I (for stems with diphthongal I-bases), CLASS II (for stems with monophthongal I-bases), and CLASS VII (for nonI-base stems).

${ }^{62}$ Pertinent regularities that have been detailed above are: first, $o$-ablaut is a general past marker; thus if it is used in the finite past it has to be used in the non-finite past a fortiori. Second, separate finite past ablaut stem forms invariably require full ablaut (and hence must be $i-, a$-, or $u$-forms). Third, short $\rightarrow$ long-alternation invariably implies full ablaut (hence finite past marking); long $\rightarrow$ short-alternation invariably implies simple ablaut (hence general past marking).
} 
cannot help agreeing with Hermann Paul's famous dictum, according to which, at long last, ablaut has attained true functional validity in Modern German. ${ }^{63}$

\section{REFERENCES}

Deutsches Wörterbuch von Jacob Grimm und Wilhelm Grimm. XVI vols., parts 1-32. Leipzig. Hirzel. 1854-1954. [Quoted as “Dt.Wb.”]

Adelung, Johann Christoph. 1782. Umständliches Lehrgebäude der Deutschen Sprache, zur Erläuterung der Deutschen Sprachlehre für Schulen. Erster Band. Leipzig: Breitkopf. [Reprint 1971, Hildesheim \& New York. (Olms Documenta Linguistica, Reihe V).]

Aldenhoff, Jules. 1961. "Doppelformen im Verbalsystem der heutigen deutschen Schriftund Umgangssprache". Revue des langues vivantes 27. 501-543.

d'Alquen, Robert. 1979. "Acoustic phonetics and vowel quantity in the history of German". Zeitschrift für Dialektologie und Linguistik 46. 187-204.

Anderson, Stephen R. 1982. "Where's morphology?'. Linguistic Inquiry 13. 571-612.

Anderson, Stephen R.. 1988. "Morphological theory". Linguistics: the Cambridge survey ed. by Frederick J. Newmeyer, vol. I: Linguistic theory: foundations, 146-191. Cambridge: Cambridge University Press.

Anderson, Stephen R.. 1992. A-morphous morphology. Cambridge: Cambridge University Press.

Aronoff, Mark. 1994. Morphology by itself: stems and inflectional classes. Cambridge, Mass.; London: MIT Press.

Augst, Gerhard. 1975. Untersuchungen zum Morpheminventar der deutschen Gegenwartssprache. Tübingen: Narr.

Barbour, J. S. 1982. "Productive and non-productive morphology: the case of German strong verbs". Journal of Linguistics 18. 331-354.

Barnes, Mervin \& Helmut Esau. 1973. "Germanic strong verbs: a case of morphological rule extension". Lingua 31. 1-34.

Bierwisch, Manfred. 1967. "Syntactic features in morphology: general problems of socalled pronominal inflection in German". To Honor Roman Jakobson, vol. 1, 239-270. The Hague \& Paris: Mouton.

Bittner, Andreas. 1996. Starke 'schwache' Verben, schwache 'starke' Verben: deutsche Verbflexion und Natürlichkeit. Tübingen. Stauffenburg.

Blevins, James P. 2003. "Stems and paradigms". Language 79. 737-767.

Bloch, Bernard. 1947. "English verb inflection". Language 23. 399-418.

Born, Renate. 1980. "Disintegration and reintegration - the history of the verbal ablaut from Proto-Germanic to Modern German". Leuvense bijdragen 69. 385-444.

Bybee, Joan \& Carol Lynn Moder. 1983. "Morphological classes as natural categories". Language 59. 251-270.

Bybee, Joan \& Dan Slobin. 1982. "Rules and schemas in the development and use of English Past Tense". Language 58. 265-289.

63 "Erst im Nhd. hat [...] der Ablaut wahrhaft funktionelle Geltung erlangt." (Paul 1920: 211). 
Chirita, Diana. 1988. Der Ausgleich des Ablauts im starken Präteritum im Frühneuhochdeutschen. Bern etc.: Lang.

Curme, George Oliver. 1922. A grammar of the German language. Second revised edition. [Ninth printing 1964]. New York: Ungar.

Drosdowski, Günther et al. 1995. Duden. Grammatik der deutschen Gegenwartssprache. 5., völlig neu bearbeitete und erweiterte Auflage. Mannheim etc.: Dudenverlag.

Durrell, Martin. 1980. "Morphonologische und morpholexische Regelmäßigkeiten im deutschen Ablautsystem". Akten des VI. Internationalen Germanisten-Kongresses Basel 1980 ed. by Heinz Rupp \& Hans-Gert Roloff, 19-28. Bern, Frankfurt a.M. \& Las Vegas: Lang.

Durrell, Martin. 2001. "Strong verb Ablaut in the West Germanic languages". Zur Verbalmorphologie germanischer Sprachen ed. by Sheila Watts, Jonathan West \& Hans-Joachim Solms, 19-28. Tübingen: Niemeyer.

Eisenberg, Peter. 1997. "Konjunktiv als Flexionskategorie im gegenwärtigen Deutsch". Studien zu Deutsch als Fremdsprache III: Aspekte der Modalität im Deutschen auch in kontrastiver Sicht ed. by Friedhelm Debus \& Oddleif Leirbukt, 37-56. Hildesheim, Zürich \& New York: Olms. (= Germanistische Linguistik, 136).

Eisenberg, Peter. 1998. Grundriß der deutschen Grammatik. Bd. 1: Das Wort. Stuttgart \& Weimar: Metzler.

Fabricius-Hansen, Cathrine. 1977. "Zur Klassifizierung der starken Verben im Neuhochdeutschen”. Deutsche Sprache 5. 193-205.

Fleischer, Wolfgang. 1974. Wortbildung der deutschen Gegenwartssprache. 3., überarb. Aufl. Leipzig: Bibliographisches Institut.

Forssman, Bernhard. 1999. "schwören, schwur, geschworen”. 'Grippe', 'Kamm' und Eulenspiegel. Festschrift für Elmar Seebold zum 65. Geburtstag ed. by Wolfgang Schindler \& Jürgen Untermann, 77-91. Berlin \& New York: de Gruyter.

Fourquet, Jean. 1970. "Les verbes forts de l'allemand: essai de classification". Les langues modernes 64. 470-477.

Grebe, Paul et al. 1959. Duden. Grammatik der deutschen Gegenwartssprache. Mannheim: Bibliographisches Institut (Dudenverlag).

Greenberg, Joseph H. 1966. Language universals: with special reference to feature hierarchies. The Hague; Paris: Mouton.

Griesbach, Heinz \& Gudrun Uhlig. 1994. Die starken Verben im Sprachgebrauch. Syntax - Valenz - Kollokationen. Leipzig etc.: Langenscheidt/Verlag Enzyklopädie.

Grimm, Jacob. 1870. Deutsche Grammatik. Erster Theil. Zweite Ausgabe. Neuer vermehrter Abdruck, besorgt durch Wilhelm Scherer. Berlin: Dümmler.

Halle, Morris. 1953. "The German conjugation". Word 9. 45-52.

Halle, Morris \& Alec Marantz. 1993. "Distributed morphology and the pieces of inflection". The view from Building 20 ed. by Kenneth Hale \& Samuel Jay Keyser, 111-176. Cambridge, Mass. \& London: MIT Press.

Hansen, Klaus. 1964. "Reim- und Ablautverdoppelungen". Zeitschrift für Anglistik und Amerikanistik 12. 5-31.

Harris, Zellig S. 1942. "Morpheme alternants in linguistic analysis". Language 18. 169-180.

Heidolph, Karl Erich et al. 1981. Grundzüge einer deutschen Grammatik. Berlin: Akademie-Verlag.

Helbig, Gerhard \& Joachim Buscha. 1987. Deutsche Grammatik: ein Handbuch für den Ausländerunterricht. 10., unveränderte Aufl. Leipzig: Verlag Enzyklopädie.

Hock, Hans Henrich \& Brian D. Joseph. 1996. Language history, language change, and language relationship. Berlin \& New York: Mouton de Gruyter.

Hockett, Charles F. 1954. "Two models of grammatical description". Word 10. 210-233. 
Hook, Donald. 1968. "Die Klassifizierung der starken Verben in der deutschen Gegenwartssprache”. Deutsch als Fremdsprache 5. 219-221.

Jakobson, Roman. 1941. Kindersprache, Aphasie und allgemeine Lautgesetze. Uppsala: Almqvist \& Wiksell. [Engl. translation: 1968: Child language, aphasia and phonological universals. The Hague \& Paris: Mouton.]

Johnston, Jason. 1997. Systematic homonymy and the structure of morphological categories: some lessons from paradigm geometry. Diss. University of Sydney.

Jung, Walter. 1966. Grammatik der deutschen Sprache. Leipzig: Bibliographisches Institut. Kiparsky, Paul. 1973. “'Elsewhere' in phonology”. A Festschrift for Morris Halle ed. by Stephen R. Anderson \& Paul Kiparsky, 93-106. New York: Holt, Rinehart and Winston.

Kohler, Klaus J. 1995. Einführung in die Phonetik des Deutschen. 2., neubearb. Aufl. Berlin, Bielefeld \& München: Schmidt.

Köpcke, Klaus-Michael. 1999. "Prototypisch starke und schwache Verben der deutschen Gegenwartssprache". Variation und Stabilität in der Wortstruktur ed. by Matthias Butt \& Nanna Fuhrhop, 45-60. Hildesheim, Zürich \& New York: Olms. (= Germanistische Linguistik 141/142).

Kruszewski, N. [Kruševskij, Nikolaj V.]. 1881. Über die Lautabwechslung. Kasan: Universitätsbuchdruckerei.

Kuryłowicz, Jerzy. 1956. L'apophonie en indo-européen. Wrocław: Zakł. im. ossolińsk. etc.

Lejosne, Jean-Claude. 1982. Verbes fortes et verbes faibles, verbes irréguliers et réguliers: contribution à l'étude diachronique et synchronique du système verbal des langues germaniques du Westique. Diss. Paris-Sorbonne. [Unpublished, not accessible].

Lieb, Hans-Heinrich. 1975. "Oberflächensyntax". Linguistische Arbeiten und Berichte [LAB] Berlin (West) 4. 1-51.

Lieb, Hans-Heinrich. 1976. "Grammars as theories: The case for axiomatic grammar (Part II)". Theoretical Linguistics 3. 1-98.

Lieb, Hans-Heinrich. 1978. "Morphological structure and morphological meaning". Proceedings of the Twelfth International Congress of Linguists ed. by Wolfgang U. Dressler \& Wolfgang Meid, 204-208. Innsbruck: Universität Innsbruck.

Lieb, Hans-Heinrich. 1980. "Words as syntactic paradigms". Wege zur Universalienforschung ed. by Gunter Brettschneider \& Christian Lehmann, 115-123. Tübingen: Narr.

Lieb, Hans-Heinrich. 1983. Integrational Linguistics. Vol. I: General outline. Amsterdam \& Philadelphia: John Benjamins. (= Current Issues in Linguistic Theory, 17).

Lieb, Hans-Heinrich. 1992. "Paradigma und Klassifikation: Explikation des Paradigmenbegriffs". Zeitschrift für Sprachwissenschaft 11. 3-46.

Liljencrants, Johan \& Björn Lindblom. 1972. "Numerical simulation of vowel quality systems: the role of perceptual contrast". Language 48. 839-862.

Lindblom, Björn \& Olle Engstrand. 1989. "In what sense is speech quantal?". Journal of Phonetics 17. 107-121.

Martinet, André. 1955. Économie des changements phonétiques: traité de phonologie diachronique. Bern: Francke.

Martinet, André. 1957. "Phonetics and linguistic evolution". Manual of phonetics ed. by Louise Kaiser, 252-273. Amsterdam: North-Holland.

Matthews, Peter H. 1970. "Recent developments in morphology". New horizons in linguistics ed. by John Lyons, 96-114. Harmondsworth: Penguin.

Matthews, Peter H.. 1972. Inflectional morphology: a theoretical study based on aspects of Latin verb conjugation. Cambridge: Cambridge University Press. 
Mayerthaler, Willi. 1977. Studien zur theoretischen und zur französischen Morphologie. Reduplikation, Echowörter, morphologische Natürlichkeit, Haplologie, Produktivität, Regeltelescoping, paradigmatischer Ausgleich. Tübingen: Niemeyer.

Mayerthaler, Willi. 1981. Morphologische Natürlichkeit. Wiesbaden: Athenaion. [Engl. translation: 1987. Morphological naturalness. Ann Arbor: Karoma.]

Nida, Eugene A. 1948. "The identification of morphemes". Language 24. 414-441.

Paul, Hermann. 1916. Deutsche Grammatik. Band I. Halle (Saale): Niemeyer.

Paul, Hermann. 1917. Deutsche Grammatik. Band II. Halle (Saale): Niemeyer.

Paul, Hermann. 1920. Prinzipien der Sprachgeschichte. 5. Aufl. Halle (Saale): Niemeyer.

Paul, Hermann. 1989. Mittelhochdeutsche Grammatik, neu bearbeitet von Peter Wiehl und Siegfried Grosse. 23. Aufl. Tübingen: Niemeyer.

Plank, Frans. 1979. "Ikonisierung und De-Ikonisierung als Prinzipien des Sprachwandels". Sprachwissenschaft 4. 121-158.

Ramat, Paolo. 1987. "Verbi forti e verbi deboli in Germanico". Festschrift for Henry Hoenigswald ed. by George Cardona \& Norman H. Zide, 319-327. Tübingen: Narr.

Robins, Robert H. 1959. "In defence of WP". Transactions of the Philological Society 1959. 116-144.

Ross, John Robert. 1967. "Der Ablaut bei den deutschen starken Verben”. Phonologische Studien, 47-118. Berlin: Akademie-Verlag. (= studia grammatica, 6).

Schottelius, Justus Georg. 1663. Ausführliche Arbeit Von der Teutschen HaubtSprache. Braunschweig: Zilligern. [Reprint Tübingen: Niemeyer 1967, ed. by Wolfgang Hecht.]

Ségéral, Philippe. 1995. Une théorie généralisée de l'apophonie. Diss. Paris: Université Paris 7.

Ségéral, Philippe \& Tobias Scheer. 1998. "A generalized theory of ablaut: the case of Modern German strong verbs". Models of inflection ed. by Ray Fabri, Albert Ortmann \& Teresa Parodi, 28-59. Tübingen: Niemeyer.

Solms, Hans-Joachim. 1984. Die morphologischen Veränderungen der Stammvokale der starken Verben im Frühneuhochdeutschen. Untersucht an Texten des 14.-18. Jahrhunderts. Diss. Bonn.

Solms, Hans-Joachim \& Klaus-Peter Wegera. 1993. "Flexionsmorphologie".

Frühneuhochdeutsche Grammatik ed. by Oskar Reichmann \& Klaus-Peter Wegera, 164-312. Tübingen: Niemeyer.

Stedje, Astrid. 1987. "Warum nur im Germanischen? Altes und Neues zum Ablaut der starken Verben”. Studier i modern språkvetenskap (N.S.) 8. 96-113.

Stevens, Kenneth N. 1972. "The quantal nature of speech: evidence from articulatoryacoustic data". Human communication: a unified view ed. by Edward E. David, Jr. \& Peter B. Denes, 51-66. New York etc.: McGraw-Hill.

Stump, Gregory T. 2001. Inflectional morphology. A theory of paradigm structure. Cambridge: Cambridge University Press.

Tanz, Christine. 1971. "Sound symbolism in words relating to proximity and distance". Language and speech 14. 266-276.

Theobald, Elke. 1992. Sprachwandel bei deutschen Verben: Flexionsklassenschwankungen starker und schwacher Verben. Tübingen: Narr.

Ulvestad, Bjarne. 1956. "The strong verb conjugation system in German". Word 12. 91105.

Wiese, Bernd. 2000. "Warum Flexionsklassen? Über die deutsche Substantivdeklination”. Deutsche Grammatik in Theorie und Praxis ed. by Rolf Thieroff et al., 139-153. Tübingen: Niemeyer.

Wiese, Richard. 1996. "Phonological versus morphological rules: on German Umlaut and Ablaut”. Journal of Linguistics 32. 113-135. 
Wilmanns, Wilhelm. 1906. Deutsche Grammatik. Gotisch, Alt-, Mittel- und Neuhochdeutsch. 3. Abteilung: Flexion. 1. Hälfte: Verbum. Strassburg: Trübner.

Wunderlich, Dieter \& Ray Fabri. 1995. "Minimalist Morphology: an approach to inflection”. Zeitschrift für Sprachwissenschaft 14. 236-294.

Wurzel, Wolfgang Ullrich. 1970. Studien zur deutschen Lautstruktur. Berlin: AkademieVerlag.

Wurzel, Wolfgang Ullrich. 1984a. "Was bezeichnet der Umlaut im Deutschen?". Zeitschrift für Phonetik, Sprachwissenschaft und Kommunikationsforschung 37. 647-663.

Wurzel, Wolfgang Ullrich. 1984b. Flexionsmorphologie und Natürlichkeit. Ein Beitrag zur morphologischen Theoriebildung. Berlin: Akademie-Verlag. [Engl. translation: 1989: Inflectional morphology and naturalness. Kluwer: Dordrecht.]

Wurzel, Wolfgang Ullrich. 1989. "Inflectional class markedness". Markedness in synchrony and diachrony ed. by Olga Mišeska Tomić, 227-247. Berlin \& New York: Mouton de Gruyter.

Zwicky, Arnold M. 1967. "Umlaut and noun-plurals in German". Phonologische Studien, 35-45. Berlin: Akademie-Verlag. (= studia grammatica, 6).

Zwicky, Arnold M. 1990. "Inflectional morphology as a (sub)component of grammar". Contemporary morphology ed. by Wolfgang U. Dressler et al., 217-236. Berlin \& New York: Mouton de Gruyter. 